\title{
Genetics and epigenetics in obesity
}

Kerstin Rohde $^{1,2} *$; Maria Keller ${ }^{1}$; , Lars la Cour Poulsen ${ }^{3}$, Matthias Blüher ${ }^{4}$, Peter Kovacs ${ }^{1}$, Yvonne Böttcher ${ }^{1,2,3 \#}$

1 Leipzig University Medical Center, IFB Adiposity Diseases, Leipzig, 04103, Germany

2 University of Oslo, Institute of Clinical Medicine, Oslo, 0316, Norway

3 Akershus University Hospital, Department of Clinical Molecular Biology, Medical Division, Lørenskog, 1478, Norway

4 Department of Medicine, University of Leipzig, Leipzig, 04103, Germany

* authors contributed equally

\# corresponding author

\section{Corresponding author:}

\section{Yvonne Böttcher}

Permanent address:

Institute of Clinical Medicine, University of Oslo, 0316 Oslo, Norway and Akershus University Hospital, 1478 Lørenskog, Norway

E-Mail: Yvonne.Bottcher@medisin.uio.no Phone:0047-67963928

Key words: obesity, genetic variants, epigenetic markers, tissue specificity, precision medicine 
Word count: 4945 
e-mail:

Kerstin Rohde: Kerstin.Rohde@ medisin.uio.no

Maria Keller: Maria.Keller@medizin.uni-leipzig.de

Lars la Cour Poulsen: 1.1.c.poulsen@medisin.uio.no

Matthias Blüher: Matthias.Blueher@medizin.uni-leipzig.de

Peter Kovacs: Peter.Kovacs@medizin.uni-leipzig.de

Yvonne Böttcher: Yvonne.Bottcher@medisin.uio.no 


\section{Abbreviations}

ABCG1 - ATP-binding-cassette-sub-family-G member 1 gene

ABCA1 - ATP-binding-cassette-sub-family-A member 1 gene

ADRB3 - beta-3-adrenergic receptor gene

ADCY3 - adenylate cyclase-3 gene

BDNF - brain-derived-neurotrophic-factor-gene

BMAL1 - aryl hydrocarbon receptor nuclear translocator-like 1 gene

BMI - body mass index

CEPT - cholesteryl ester transfer protein gene

CLOCK - clock-circadian-regulator gene

CT - computed tomography

DNMT3B - DNA-methylase-3B gene

DXA - dual-energy X-ray absorption

FOXP2 - forkhead-box-protein-P2 gene

FTO - fat-mass-and-obesity-associated gene

GWAS - genome-wide association studies

HbA1c - glycated hemoglobin (A1c)

HDAC4 - histone-deacetylase-4 gene

HDL-c - high density lipoprotein cholesterol

HIF3A - hypoxia induced factor 3 A gene

HLA-C - major histocompatibility complex, class $C$

HSD2 - 11 beta-hydroxysteroid dehydrogenase type 2 gene

IL17RA - interleukin-17 receptor-A gene

ILIB - interleukin-1B gene

IL6 - interleukin-6 gene

IGF2/H19 - insulin-like growth factor2/H19 imprinting control region IRS1 - insulin-receptor 1 gene 
IRX3 - iroquois-homeobox 3 gene

IRX5 - iroquois-homeobox 5 gene

KCNQ1 - potassium voltage-gated channel subfamily q member 1 gene

LDL-c - low density lipoprotein cholesterol

LEP - leptin gene

LEPR - leptin receptor gene

LY86 - lymphocyte antigen-86 gene

MAP2K5 - mitogen-activated protein kinase kinase 5 gene

MCHR1 - melanin-concentrating hormone receptor 1 gene

MC4R - melanocortin-4-receptor gene

MRI - magnet resonance imaging

NEGR - neurogranin gene

$N P Y$ - neuropeptide-Y gene

PCSK1 - prohormone-convertase-1 gene

PDK4 - pyruvate dehydrogenase kinase-4 gene

PER2 and 3 - period circadian 2 and 3 genes

PHGDH - phosphoglycerate dehydrogenase gene

POMC - pro-opio-melanocortin gene

PPARG-peroxisome-proliferator-activated receptor gamma gene

PPARGC1A - PPARG coactivator-1-alpha gene

RPTOR - regulatory associated protein of mTOR complex 1 gene

RYGB - Roux-en Y gastric bypass

T2D - type 2 diabetes

TMEM18 - transmembrane protein-18 gene

TNFA - tumor necrosis factor-alpha gene

SIM1 - single-minded homolog-1 gene

SNP - single nucleotide polymorphism 
SORBS3 - sorbin and sh3 domain containing-3 gene

SRBF1 - sterol-regulatory element binding transcription factor-1 gene

TCF7L2 - transcription factor-7-like-2 gene

TOMM20 - translocase of outer mitochondrial membrane-20 gene

WHR - waist to hip ratio 


\section{Summary}

Obesity is amongst the most threatening health burdens worldwide and its prevalence has markedly increased over the last decades. Obesity maybe considered a heritable trait. Identifications of rare cases of monogenic obesity unveiled that hypothalamic circuits and the brain-adipose axis play an important role in the regulation of energy homeostasis, appetite, hunger and satiety. For example, mutations in the leptin gene cause obesity through almost unsuppressed overeating. Common (multifactorial) obesity, most likely resulting from a concerted interplay of genetic, epigenetic and environmental factors, is clearly linked to genetic predisposition by multiple risk variants, which, however only account for a minor part of the general BMI variability. Although GWAS opened new avenues in elucidating the complex genetics behind common obesity, understanding the biological mechanisms relative to the specific risk contributing to obesity remain poorly understood. Non-genetic factors such as eating behavior or physical activity strongly modulate the individual risk for developing obesity. These factors may interact with genetic predisposition for obesity through epigenetic mechanisms. Thus, here, we review the current knowledge about monogenic and common (multifactorial) obesity highlighting the important recent advances in our knowledge on how epigenetic regulation is involved in the etiology of obesity.

\section{Introduction}

The prevalence of obesity is increasing dramatically globally not only in well-developed countries but also in developing countries [1] impacting on public health around the globe and causing a formidable socioeconomic challenge. Obesity significantly shortens the life expectancy [2] and contributes to multiple cardio-metabolic diseases such as T2D, dyslipidemia, coronary artery disease, stroke, hypertension and numerous non-metabolic comorbidities (e.g. reflux disease, several types of cancer including esophageal adenocarcinoma, non-alcoholic steatohepatitis, liver cirrhosis and hepatocellular carcinoma, sleeping problems, depression, or musculoskeletal diseases) [3-5]. While a very small proportion of obesity cases result from monogenic alterations, the increasing prevalence of common (multifactorial) obesity during the last 50 years is most likely due to a complex interplay of environmental changes ("obesogenic environment") and the individual genetic predisposition. Despite major evidence for an important role of environmental factors such as sedentary lifestyle combined with intake of energy dense nutrition and reduced energy expenditure there is no doubt for a 
strong genetic basis of common obesity. Early evidence stemming from family [6-9], twin [10-12] and adoption [13] studies revealed heritability estimates for BMI of up to 70-80\% and recent studies in ethnically diverse populations underline the relevance of genetic contribution [14]. Over the past decade, GWAS, based on their hypothesis free nature, has emerged as an excellent tool for identifying novel and unexpected genes as well as loci contributing to obesity $[15,16]$. Most of these studies have been conducted in individuals of Caucasian ancestry $[15,16]$, while fewer reports describe the genetic architecture of obesity in other populations e.g. Africans or apply transethnic analyses in ancestrally diverse populations [17] [18]. GWAS revealed important novel insights into genetics of obesity, however, a major limitation in understanding the genetic contribution is owed to the large proportion of unexplained variability of BMI, as identified SNP markers collectively explain less than 3\%-5\% of the observed variability $[15,19]$. A more recent study however, estimated a lower genetic heritability for BMI (30-40\%) compared to early studies by using millions of imputed genetic variants in ten-thousands of individuals [20]. It suggested that the missing heritability for obesity is rather negligible, which may point towards a potential limitation of heritability estimates with the use of incomplete genetic information [20]. Still, the undoubtedly important influence of environmental factors contributes to the variability evident in the etiology of obesity as a large body of evidence has emerged for substantial individual variability induced by gene-environment interactions. Furthermore, non-genetic factors (e.g. nutrition, exercise or weight loss interventions) induce dynamic alterations in the epigenetic signatures, which in turn modulate gene activity. Indeed, strong correlations were observed between clinical variables relevant for obesity and epigenetic patterns from whole blood, adipose tissue, liver or skeletal muscle, while however, cause and consequence of these relationships are still not well understood [21-24].

One ultimate goal for future clinical obesity treatment and intervention is to define individual risk profiles based on a combination of genetic and non-genetic factors that may be helpful in both predicting personal risk for obesity and its accompanying diseases and estimating response to treatment and interventions. This review aims at summarizing the current knowledge of genetics of obesity including monogenic (syndromic and non-syndromic) and common (polygenic) forms of obesity, gene-environment interaction in obesity, and current advancements in the study of epigenetic alterations that are related to (or potentially causative for) obesity. We put this into context of potential future precision medicine efforts. 


\section{Genetic background of obesity}

\section{Monogenic syndromic and non-syndromic obesity}

Monogenic obesity results from a single gene mutation. It can be syndromic, or nonsyndromic. Despite in accordance to Mendelian inheritance, syndromic monogenic obesity is co-presented with other characteristics, such as cognitive delay, dysmorphic features and organ-specific abnormalities [25]. To date, 79 different syndromes have been identified, amongst which, only 19 have been completely characterized genetically; 11 have been partially elucidated; 27 are mapped to a chromosomal region: and the remaining 22 remain elusive, with neither the gene(s) nor the chromosomal location(s) identified [25]. The best characterized syndromes with obesity are Prader-Willi syndrome (imprinting defect in the region on chromosome 15q11-13), Prader-Willi like syndrome (several deletions on chromosome 16, including SIMI [26]), Fragile X syndrome (with features of Prader-Willi syndrome), Bardet-Biedl syndrome (19 genes reported to date), Albright's hereditary osteodystrophy (GNAS1 mutation) and WAGR (Wilms-Tumour-Aniridia-Syndrom) syndrome (chromosome 11p14 deletions) (reviewed in [27]).

As for non-syndromic monogenic obesity, there are well-recognized genes, each playing a role in the regulation of energy homeostasis mediated by the leptin-melanocortin pathway [28, 29]. Although extremely rare, homozygous loss-of-function mutations in genes such as MC4R, LEP, LEPR, PCSK1, ADCY3 and POMC result in fully penetrant monogenic obesity. In contrast, 2-3\% of common (oligogenic) obesity in adults and children is mostly attributed to heterozygous coding mutations in these genes [30] and is characterized by a variable severity of obesity partly dependent on environmental factors [31].

Discovery of the leptin gene mutation in severely obese $o b / o b$ mice [32] and mutations in rare cases of extremely obese children paved a path for identifying rare genetic mutations in obesity. Leptin signaling modulates energy balance through a combination of melanocortindependent/independent pathways [33]. Through leptin and its receptor, the hypothalamus receives signals from adipose tissue indicating sufficient energy stores in the body. Mutations in leptin result in hyperphagia, lower locomotor activity, reduced sympathetic tone, mild hypothyroidism, hypogonadism, and impaired T-cell-mediated immunity. Treatment with recombinant human leptin can relieve the symptoms resulting from impaired leptin signaling [34-37]. At molecular level, leptin stimulates neurons expressing POMC, whose gene product promotes production of alpha-melanocyte-stimulating hormone ( $\alpha$-MSH) binding to MC4R. Given their physiologic relevance in energy homeostasis, it is not surprising that mutations in 
$P O M C$ [38] and MC4R also result in severe obesity [39]. Human loss-of-function mutations in $M C 4 R$ result in increased food intake, increased lean mass and linear growth [39]. It is of note that heterozygous $M C 4 R$ mutations are observed in up to 5\% of people with childhood obesity, making this the commonest gene in monogenic obesity [40, 41]. Melanocortin peptides are processed by enzymes such as prohormone convertase 1 (PCSK1) [42]. Patients with homozygous and compound heterozygous mutations in PCSK1 have altered POMC processing and manifest obesity accompanied by glucocorticoid deficiency, hypogonadotropic hypogonadism, and postprandial hypoglycemia [43, 44]. Finally, SIM1, a transcription factor involved in the development of the paraventricular and supraoptic nuclei of the hypothalamus has to be acknowledged. Siml may be involved in signaling downstream of Mc4r [45] and SIM1 loss-of-function mutations cause severe obesity in humans [26, 46, 47].

\section{Common obesity}

Despite the significant contribution of monogenic obesity to our general knowledge on genetics and physiology of body weight regulation, the majority of the individuals with obesity develop "common (multifactorial) obesity" which is attributed to the interplay between multiple loci (polygenic), though each with rather small effects on BMI and the “obesogenic" environment. Whilst candidate gene and genome-wide linkage approaches have not been tremendously successful in identifying relevant genetic contributors to obesity, the advent of GWAS has led to the discovery of novel genetic factors associated with obesity, e.g. FTO [48]. So far, more than 870 SNPs strongly associated with BMI have been identified in large scale GWAS within international consortia such as (the Genetic Investigation of ANthropometric Traits) GIANT [15, 19] or other well-powered studies [49]. The GWAS findings indicate that despite identification of hundreds of loci associated with obesity, they only explain $5 \%$ of the variance of BMI [19]. Thus, explaining the remaining variability appears to be highly challenging and will definitely influence future research focus in this field. Nevertheless, recent advances in genome-wide strategies have clearly demonstrated that loci associated with obesity carry genes involved in pathways affecting neuro-circuits of appetite and satiety regulation (BDNF, MC4R, and NEGR) [50-53], insulin secretion and action (TCF7L2, IRS1) [53, 54], adipogenesis [55] and energy and lipid metabolism (FTO, RPTOR, MAP2K5 [48, 53, 54]). Further, gene ontology analyses in genes overlapping with obesity-related diseases (e.g. diabetes, hypertension, coronary artery disease) have revealed "gene modules" that provide common shared GO pathways for these diseases [56]. It is also of note, that in addition to rare loss of function variants resulting in non-syndromic 
monogenic obesity, several common polymorphisms in PCSK1 [57-59], MC4R [60] and POMC have been strongly associated with polygenic obesity in ethnically diverse population. Without doubts, GWAS are a powerful tool to reveal common variants contributing to common polygenic traits and diseases, but the interpretation of these findings is challenging. Most of the "obesity" SNPs map within non-coding regions carrying regulatory elements that are essential for gene regulation. However, the respective target genes of these variants are not necessarily the genes for which they have been attributed (simply based on the location within the gene). For instance, it took $\sim 7$ years to clarify the regulatory circuitry and mechanistic basis of the associations between FTO variants and obesity. Ultimately, Claussnitzer et al. demonstrated that an intronic FTO SNP associated with BMI resides within an enhancer element for ARID5B which regulated the expression of IRX3 and IRX5, which in turn affect thermogenesis, lipid accumulation and adipogenesis [61].

Sophisticated functional studies are required to understand the underlying molecular mechanisms of obesity-associated genes unveiled by GWAS and their contribution to obesity and its related traits.

\section{Gene - environment interaction in obesity}

The role of genetic and environmental factors (particularly physical activity and dietary) have been addressed in numerous genetic and epidemiological studies. Although studies targeting gene - environment interactions $(\mathrm{GxE})$ have emerged rapidly in the last decade, the results are still rather inconclusive. The main focus has been placed on the interactions between polymorphisms associated with obesity and environmental modulators of obesity risk such as age, sex, physical activity, diet, socioeconomic and educational status and ethnicity. For instance, physical activity has been shown to reduce the genetic predisposition to obesity for FTO [62, 63], but also for a combination of 12 obesity-associated SNPs [64]. In addition, dietary habits have been extensively studied in the context of GxE. It has been shown in the Nurses' Health Study (NHS), the Health Professionals Follow-up Study (HPFS), and the Women's Genome Health Study (WGHS) that genetic associations with obesity based on 32 BMI variants were stronger among subjects with higher intake of sugar-sweetened beverages than among those with lower intake [65]. Similarly, in the same cohorts, genetic association with adiposity seemed to be more pronounced with higher consumption of fried foods [65]. In line with the described interaction with physical activity, this study demonstrated that the genetic association with BMI was strengthened by sedentary lifestyle as represented by increased hours of TV watching but weakened in participants with increased physical activity 
[65]. Individual variants in FTO have been shown to interact with dietary habits. A highprotein diet had beneficial effects on weight loss and improvement of body composition in carriers of the FTO obesity risk allele rs1558902 [66]. Moreover, subjects with the FTO rs9939609 A allele achieved a better metabolic outcome in response to weight loss after on a low-fat hypocaloric diet [67].

One of the major lessons we have learned so far is that unfavorable effects of obesity variants can be compensated by behavioral changes such as improving diet and physical activity [68]. Despite the challenges in the understanding of GxE, there is strong evidence to progress and to intensify research in this field. Investments in the respective research will not only provide deeper insights into molecular mechanisms behind GxE, essential for improvement of treatment, but also help to identify individuals for more efficient targeted anti-obesity interventions.

Admittedly, GxE interactions are unlikely to contribute significantly to risk prediction [69]. However, GxE interactions seem to account for some of the missing heritability underlining the importance of epigenetic signatures as potential mediator for GxE [70]. Considering the metabolic diversity of obesity, epigenetic modifications such as DNA methylation are very likely representing one of the determining factors and may constitute another level of regulation in mediating disease risk.

\section{Epigenetic signatures in obesity: Fine tuning the genome - beyond genetic factors}

Epigenetic mechanisms are modifications prior to or post translation regulating gene activity without changing the genomic sequence $[71,72]$. In this review we focus on DNA cytosine (C) methylation $(\mathrm{CpG})$ which is the best studied and most stable epigenetic mechanism $[73,74]$.

\section{Genome wide DNA methylation analysis in obesity and associated traits}

In the recent years multiple studies analyzed DNA methylation at $\mathrm{CpG}$ sites on a genome wide level and its potential relationship with common obesity and clinical variables related to obesity and adipose tissue distribution $[24,75]$.

Here, we review studies analyzing DNA methylation profiles mainly in human adipose tissue, and whole blood in Caucasian populations that formed the research field during the last 5 years (Table 1). For instance, Dick et al. [75] showed that increased methylation at HIF3A was linked to higher BMI and this relationship was present in both subcutaneous adipose tissue (SAT) and whole blood which was successfully replicated by others [76-79]. Other 
studies identified significant correlations of multiple genes (either involved in insulin and glucose metabolism, adipogenesis or early development) with BMI or other clinical variables related to obesity and adipose tissue distribution (e.g. waist circumference, WHR, summarized in Table 1). Most of these studies used adipose tissue (SAT) [75, 80-84] and/or whole blood samples $[24,75,80,85]$. Others reported strong methylation differences between individuals with and without metabolic syndrome (MetS+vs. MetS-) which were measured in visceral adipose tissue (VAT) [86-88]. VAT might represent an ideal target tissue for detecting potential biomarkers for MetS since increased abdominal fat accumulation is known to be associated with impaired insulin sensitivity and altered lipid profiles [89]. The majority of studies investigated, in addition to DNA methylation changes, mRNA expression differences underlining the close relationship between methylation changes and transcriptome levels. However, it is noteworthy that far from all observed methylation differences translate into changes in gene activity, an observation that is poorly understood so far [22, 90]. In conclusion, genome wide DNA methylation analyses provided evidence for a strong correlation of epigenetic patterns with clinical variables. However, despite indications from whole blood derived epigenetic changes being secondary to metabolic changes [24], no final conclusions can yet be drawn whether alterations in clinical variables related to common obesity are cause or consequence of epigenetic modifications, particularly for other tissue specific epigenetic profiles.

\section{Studies analyzing the correlation between genetic variants and DNA methylation}

Despite evidence for a clear relationship between epigenetic patterns and clinical traits, the interpretation of the causal relationship between the observed alterations in DNA methylation and obesity is still challenging. Genetic variants can introduce or delete methylation sites in CG context, thereby induce changes in DNA methylation at the SNP site. Moreover, SNPs located in cis or trans of the $\mathrm{CpG}$ site can alter action of methylation enzymes. To further test for potential interactions between epigenetic profiles and genetic factors several studies (Table 1) performed correlation analyses of DNA methylation and SNP genotypes. These methylation quantitative trait locus (meQTLs) analyses are valuable tools to understand whether DNA methylation changes represent a) a mediator between genetic predisposition and clinical variables, b) consequences of the interaction between genotype and phenotype or c) the effects between genotype and methylation are independent from the genotypephenotype associations. One recent study used Mendelian randomization and a weighted genetic risk score, generated by SNPs known to affect BMI, in order to elucidate whether 
DNA methylation changes in blood are cause or consequence of adiposity [24]. The authors found a strong correlation between predicted and observed effects of BMI genetic risk score on methylation $\left(\mathrm{R}^{2}=0.65 ; \mathrm{P}=4.7 \times 10^{-44}\right)[24]$. They further showed an association between the risk score and DNA methylation of $A B C G 1$ which is in line with other reports suggesting that weight loss influences $A B C G 1$ methylation, expression and protein activity [91, 92]. Finally, Wahl et al. suggested that DNA methylation changes in blood represented most likely the consequence of obesity rather than the cause [24]. However, it is still under debate whether and if so, to which extent evidence stemming from whole blood can be transferred to the potential target tissue. In contrast, Volkov et al. demonstrated by using a causal inference test (CIT), that genetic variants interfere with different metabolic traits such as BMI, HbA1c, and HDL-cholesterol (HDL-c) via altered DNA methylation in human adipose tissue [93]. Others reported meQTLs in whole blood and adipose tissue (depot-specific meQTLs in SAT and OVAT) associated to BMI or metabolic traits [85, 94]. For instance, a SNP variant in $A D C Y 3$ was found to be related to proximal $\mathrm{CpG}$ site methylation in whole blood [85] but also in SAT [94]. Combined information of genetic variation, gene expression and DNA methylation might help to better understand potentially causative relationships with clinical traits. Genetic variants can modulate methylation status of $\mathrm{CpGs}$ sites and to induce comethylation patterns at nearby sites that may finally translate into alterations of clinical traits, suggesting a genotype-phenotype correlation.

\section{Candidate gene approaches for DNA methylation in obesity and associated traits}

Numerous studies (Table 2) provide insights into DNA methylation contributing to obesity and metabolic syndrome mainly through pathways involved in eating behavior, circadian rhythm but also lipid metabolism. For instance, the adipokines leptin and adiponectin mediate hunger and satiety, and DNA methylation at these genes (LEP in blood and ADIPOQ in SAT) was associated with BMI and LDL cholesterol levels [95]. Moreover, body fat mass has been shown to be related to both leptin and adiponectin gene DNA methylation [96]. Interestingly, candidate genes involved in monogenic obesity such as POMC [97], are also subject of epigenetic changes contributing to common obesity $[98,99]$. Blood derived DNA methylation levels of $P O M C$ were linked to BMI with higher levels in obese compared to normal weight adults and children [98, 99]. Furthermore, weight regain is associated with increased methylation of $P O M C$ but with lower blood methylation levels of $N P Y$ while the latter was linked to hunger and satiety controlling peptides leptin and ghrelin [100]. Interestingly, in obese individuals methylation of POMC was also higher in $\mathrm{MSH}$-positive neurons 
(melanocyte stimulating hormone) compared to lean counterparts, suggesting a regulatory function of methylation on the downstream pathway of POMC [100].

Another important mechanism associated with obesity is circadian rhythm, where clock-genes contribute to a $24 \mathrm{~h}$ rhythm underlying physiological processes. Differences in blood $\mathrm{CpG}$ methylation of important clock-genes such as BMAL1, PER2 and 3 and CLOCK were found between lean and obese adults and children [101-103].

Different nutrients have been shown to correlate with changes in DNA methylation for a variety of obesity associated genes, including TNFA, IGF2/H19, LEP, the circadian genes (CLOCK, BMAL1 and PER2), HSD2, MCHR1, LY86 [101, 104-108]. Methylation of IGF2/H19 and HSD2 has been linked to maternal diet (increased protein and reduced carbohydrate intake) during pregnancy [96] and methylation of LEP has been linked to the duration of breast feeding [104-106]. Mostly, various lipids have been linked to changes in DNA methylation, such as n-6 PUFAs for TNFA, components in hazel nut oil for ADRB3, other fatty acids for $C L O C K$ and triglycerides for ABCG1, ABCA1, PHGDH, TOMM20 [101, 104, 109-113]. The majority of these genes play a role in lipid metabolism suggesting that, a) lipids induce dynamic changes in DNA methylation and b) alterations in DNA methylation can impact on lipid pathway genes being of immense importance for the development of obesity and co-morbidities. This is further reinforced by studies highlighting an association of blood lipid levels with genome-wide DNA methylation while affecting transcription of numerous genes involved in lipid metabolism [114, 115].

DNA methylation of certain genes significantly differs between adipose tissue depots [22, 116] [81], which correlate with alterations in metabolic variables and fat distribution. Most studies hint on changes of DNA methylation in subcutaneous adipose tissue (SAT) being critical for an unfavorable metabolic outcome in regard to comorbidities of obesity [116]. For instance, while DNA methylation in the promoter region of TMEM18, a previously identified GWAS candidate gene for BMI, is higher in OVAT compared to SAT, methylation levels in SAT were positively associated with BMI, visceral fat mass and also metabolic parameters [117]. Moreover, ADIPOQ and LEP DNA methylation in SAT was correlated with increased BMI, waist circumference and/or LDL-C level and MCHR1 methylation in SAT was related to weight gain upon high fat diet $[95,107]$. However, omental visceral adipose tissue (OVAT) methylation of specific genes is also linked to parameters of fat distribution as well as glucose metabolism in an unfavorable way as shown for IRSI [118]. These studies suggest that gene 
specific DNA methylation differences in SAT and OVAT contribute to the pathophysiology of obesity and underline the importance of tissue specific gene regulation. Therefore, applying blood methylation levels as surrogate markers for methylation status in adipose tissue were proven useful only for a limited number of genes such as $H I F 3 A$ and clearly need further investigations [76].

In conclusion, gene specific DNA methylation in obesity is tissue specific and seems to be highly affected by lipid metabolites and other dietary factors. There is no doubt that changes in DNA methylation at certain genes do correlate not only with BMI and overall obesity, but also with the development of comorbidities such as T2D or dyslipidemia.

\section{Lessons from intervention studies}

Numerous intervention studies examining the effects of physical activity or weight loss due to bariatric surgery on DNA methylation clearly corroborates the vast evidence for correlations of clinical variables with epigenetic signatures. An early study [119] reported dynamic alterations in skeletal muscle DNA methylation at PPARGC1A, PDK4 and PPARD induced by acute exercise intervention. Accordingly, others [120] have observed significant improvements in lipid metabolism and increased content of mitochondria in human myotubes after 12 weeks of extensive endurance and strength training comparing lean and overweight men. Lund et al. [120] further discovered decreased IRSI mRNA expression along with higher DNA methylation levels in response to exercise in cultured human myotubes. Recently, Bajpeyi et al. [121] provided evidence that PPARGC1A DNA methylation discriminates high vs. low responders post-exercise. Similar to the observed epigenomic plasticity in skeletal muscle, exercise intervention also induces genome wide changes in DNA methylation in human adipose tissue. Rönn et al. [90] described altered DNA methylation in SAT after a six months exercise intervention. These alterations were confirmed in mouse adipocytes and potentially affect adipocyte metabolism [90]. Further, others have shown that individual training status alters the genomic response on epigenetic and transcriptomic levels to acute exercise [122]. Interestingly, significant epigenomic remodeling in sperm was observed after short-term endurance training [123]. One of the scarce intervention studies in overweight adolescents investigated DNA methylation signals derived from whole blood before and after 6 months of high-intensity interval training (HIIT) [124]. While providing significant evidence for beneficial effects on body composition and cardio-metabolic health, there were no epigenetic changes [124]. 
Other interventions, most importantly those inducing significant weight loss such as bariatric surgery have shown evidence for dynamic epigenetic tissue-specific changes in association with improved metabolic health. DNA promoter methylation levels in skeletal muscle at PPARGC1A and PDK4 were, after gastric bypass surgery, restored to levels comparable with non-obese individuals [21]. Similarly, altered promoter methylation in blood was shown for PDK4, ILIB, IL6, and TNFA 12 months after RYGB [125]. Dynamic changes in DNA methylation were observed for SORBS3 in human skeletal muscle, showing that RYGB intervention restored DNA methylation levels to normal levels [126]. Others reported differential modifications in DNA methylation at several genes (CEPT, FOXP2, HDAC4, DNMT3B, KCNQ1, HOX genes) in adipose tissue following gastric bypass surgery [127]. Accordingly, a similar study revealed specific differentially methylated loci between SAT and OVAT before and after weight loss surgery [128]. Others described changes in DNA methylation levels after RYGB related to improvements in fatty acid metabolism [129] and systolic blood pressure [130]. Interestingly, comparing the methylomes of siblings born either before or after maternal bariatric intervention, revealed evidence for a large number of differentially methylated genes, including genes important for insulin receptor and leptin signaling. These data suggest that maternal weight loss may affect the methylomes of offsprings [131]. Moreover, other data show clear evidence for epigenomic changes in human spermatozoa which are significantly altered after weight loss [132].

In summary, there is evidence for a strong relationship between behavioral changes induced by weight loss surgery or exercise interventions and epigenetic changes that in turn may contribute to beneficial metabolic effects.

\section{Precision medicine in obesity - a long way to go}

In monogenic obesity individualized counseling is possible through genetic testing of candidate genes such as $L E P, L E P R, M C 4 R$ and POMC. Mutations in LEP result in severe leptin deficiency, which could be treated by administration of recombinant leptin [35]. Recently, strong evidence was reported for treating severe obesity in individuals with mutations in LEPR with a novel MC4R agonist setmelanotide [133]. Similarly, as described in two rare cases of POMC deficiency, application of $\alpha$-melanocyte-stimulating hormone analogue induced significant weight loss [134]. It has been reported that children carrying mutations in MC4R and POMC were able to lose weight through changes in lifestyle [135, 136], but were at a high risk of weight regain. Taken together, personalized treatment in 
monogenic obesity is established for genetic mutation screening, and treatment scenarios for rare cases are available for mutations in $L E P, L E P R$ or $P O M C$.

Individual treatment taking into account personal risk profiles and response to various treatment options is considered to become the most effective therapeutic approach also for complex diseases in the future [137-139]. Therefore, biomarkers suitable for powerful precision medicine approaches to fight common obesity shall have a high potential in predicting risk or response to treatment and/or intervention (Figure 1). Individualized treatment may include personalized type of exercise intervention, diet and specific medication (Figure 1). Although tremendous technological advances opened new avenues in deciphering the genetic architecture of common obesity [15, 16], precision medicine aiming at individualized therapy, its co-morbidities and related clinical variables is still in its infancy [140]. As SNP markers confer small effect sizes and genetic risks scores have a relatively low predictive value, genetic markers do not fulfill criteria of suitable biomarkers in precision medicine so far. Further limitations lie in the large inter-individual variability in clinical variables [141] which additionally hampers individualized treatment. Nonetheless, significant progress has been made in establishing large genetic databases and bioinformatics tools, which will prove extremely useful in future efforts deciphering individual phenotypic variability [142]. Importantly, GxE interactions that influence personal outcome on weight loss or regain, diet intervention or life-style changes [62-66] further increase the interindividual variability whilst the risk prediction is not significantly improved when combined with genetic scores [69].

Taking into account the influence of environmental factors on the etiology of obesity, highlights the importance of including epigenetic markers in future precision medicine efforts (Figure 1). Indeed, numerous studies have emphasized strong relationships between DNA methylation and important clinical traits. Moreover, growing evidence suggests that such modifications are reversible and can be dynamically altered by environmental factors such as physical activity, nutrition or weight loss. In the context of obesity-related co-morbidities, which is per se strongly related to adipose tissue distribution, there is also evidence for a clear depot-specificity differentially influencing clinical traits. Although epigenetic markers alone are most likely insufficient to serve as biomarkers towards precision medicine, the effect size and direction of a non-causative correlation with clinical traits may still be informative as a prognostic or diagnostic tool in combination with other markers such as genetic variants. Moreover, for precision medicine to become part of clinical practice in the future, analysis of circulating epigenetic biomarkers from whole blood as a surrogate tissue would be a preferred 
scenario, which is still challenging with regard to the described tissue specificity of epigenetic patterns. So far, clinical applications of precision medicine in common obesity are limited and further progress in identifying and validating suitable biomarkers is warranted.

\section{Closing remarks}

Prevention and treatment of obesity is challenging, because the interplay of biologic including genetic obesity risk factors with the obesogenic environment is incompletely understood. Epigenetic modifications may translate the environment and behavior into individual biologic responses, which may contribute to obesity and its comorbidities. However, how eating habits, food preference and physical activity affect gene expression through epigenetic mechanisms are not known to an extent that it could be used for a personalized prevention or treatment of obesity. Therefore, future research should clarify whether: a) rare genetic variants conferring larger effect sizes can partially account for the BMI variability unexplained by genetic

variation; b) SNP markers associated with obesity in cross-sectional settings overlap with those contributing to changes in body weight in weight loss interventions, c) epigenetic modifications in circulating blood cells could be used as "biomarkers" for parallel epigenetic changes in tissues relevant in the etiology of obesity. 


\section{Funding}

YB, MK and PK are supported by IFB AdiposityDiseases. IFB AdiposityDiseases is supported by the Federal Ministry of Education and Research (BMBF), Germany, FKZ: 01EO1501. KR was funded the European Union Seventh Framework Programme (FP7PEOPLE-2013-COFUND) under agreement n609020-Scientia Fellows. LLCP was funded by a research grant from Norwegian regional health authority Helse Sør-Øst (to YB). Further support was obtained from the Deutsche Forschungsgemeinschaft for a Collaborative Research Center (CRC 1052/2): “Obesity mechanisms” (B1 to MB; B3 to PK).

\section{Disclosure statement}

The authors have nothing to disclose.

\section{Author contributions}

All authors were responsible for the conception and design of the manuscript, drafting the manuscript, revising it critically for intellectual content and approving the final version.

Acknowledgement

We thank Dr. Yahyah Aman for proofreading our manuscript and thorough language editing. 


\begin{tabular}{|c|c|c|c|c|c|c|}
\hline $\begin{array}{l}\text { Clinical } \\
\text { variable }\end{array}$ & $\begin{array}{l}\text { Study } \\
\text { reference }\end{array}$ & $\begin{array}{l}\text { Population size, } \\
\text { gender equality } \\
(\mathrm{y} / \mathrm{n})\end{array}$ & Tissue type & Analysis technique & Top gene(s) & Main findings \\
\hline \multicolumn{7}{|c|}{ Genome-wide DNA methylation studies } \\
\hline BMI & $\begin{array}{l}\text { Dick et al. } \\
\text { Lancet, } 2014 \\
{[75]}\end{array}$ & $479 / n$ & WB, SAT, skin & $\begin{array}{l}\text { Infinium Human } \\
\text { Methylation } 450 \\
\text { BeadChip }\end{array}$ & HIF3A & $\begin{array}{l}5 \text { CpGs mapping for } 3 \text { genes showed } \\
\text { significant association to BMI, } \\
\text { association for one of the genes } \\
\text { could be replicated in adipose tissue }\end{array}$ \\
\hline BMI & $\begin{array}{l}\text { Dahlmann et } \\
\text { al. Int J } \\
\text { Obesity, } \\
2015 \text { [83] }\end{array}$ & $30 / \mathrm{n}$ & $\begin{array}{l}\text { abdominal } \\
\text { subcutaneous } \\
\text { fat cells }\end{array}$ & $\begin{array}{l}\text { Infinium Human } \\
\text { Methylation } 450 \\
\text { BeadChip }\end{array}$ & $\begin{array}{l}I G F 1 R, I R S 2, \text { FASN }, R G S 3, \\
T G F B 2\end{array}$ & $\begin{array}{l}248 \text { genes showed significant } \\
\text { methylation differences between post } \\
\text { obese and never obese subjects. }\end{array}$ \\
\hline $\begin{array}{l}\text { BMI/ } \\
\text { waist (cm) }\end{array}$ & $\begin{array}{l}\text { Aslibekyan } \\
\text { et al. } \\
\text { Obesity, } \\
2015 \text { [143] }\end{array}$ & $991 / y$ & $\begin{array}{l}\text { CD4+ cells } \\
\text { from PB }\end{array}$ & $\begin{array}{l}\text { Infinium Human } \\
\text { Methylation } 450 \\
\text { BeadChip }\end{array}$ & $\begin{array}{l}C P T 1 A, P H G D H, C D 38 ; \text { long } \\
\text { intergenic non-coding RNA } \\
00263\end{array}$ & $\begin{array}{l}8 \quad \text { CpGs showed significant } \\
\text { association with } \mathrm{BMI} \text { and } 5 \mathrm{CpGs} \\
\text { with waist circumference }\end{array}$ \\
\hline MetS & $\begin{array}{l}\text { Guénard et } \\
\text { al. Physiol } \\
\text { Genomics, } \\
2014[86]\end{array}$ & $14 / \mathrm{n}$ & VAT & $\begin{array}{l}\text { Infinium Human } \\
\text { Methylation } 450 \\
\text { BeadChip }\end{array}$ & $\begin{array}{l}\text { MetS+ vs. MetS-: TBL1X } \\
\text { MYADML2, UVSSA, } \\
\text { GMCL1L, MAPK10, } \\
\text { LOC150935 }\end{array}$ & $\begin{array}{l}3258 \text { annotated genes showed } \\
\text { significant methylation differences } \\
\text { between MetS+ and MetS- subjects. } \\
\text { Most overrepresented pathways relate } \\
\text { to structural components of the cell } \\
\text { membrane, inflammation and } \\
\text { immunity and cell cycle regulation. }\end{array}$ \\
\hline $\begin{array}{l}\text { MetS/ } \\
\text { metabolic } \\
\text { traits }\end{array}$ & $\begin{array}{l}\text { Allum et al. } \\
\text { Nat } \\
\text { Commun, } \\
2015 \text { [88] }\end{array}$ & $72 / ?$ & VAT & MCC-seq & CD36 & $\begin{array}{l}\text { Identified novel variation within } \\
\text { enhancers strongly correlated to } \\
\text { plasma triglyceride and HDL- } \\
\text { cholesterol, MCC-Seq provides } \\
\text { comparable accuracy to alternative } \\
\text { approaches but enables more efficient } \\
\text { cataloguing of functional and disease- } \\
\text { relevant epigenetic and genetic } \\
\text { variants for large-scale EWAS. }\end{array}$ \\
\hline
\end{tabular}




\begin{tabular}{|c|c|c|c|c|c|c|}
\hline \multicolumn{7}{|c|}{ meQTL studies } \\
\hline BMI & $\begin{array}{l}\text { Voisin et al. } \\
\text { Genome } \\
\text { Med, } 2015 \\
{[85]}\end{array}$ & $355 / y$ & WB & $\begin{array}{l}\text { Infinium Human } \\
\text { Methylation } 450 \\
\text { BeadChip, } \\
\text { Illumina Golden Gate } \\
\text { Assay }\end{array}$ & $\begin{array}{l}\text { MIR148A, BDNF, PTPMT1, } \\
\text { NRIH3, MGAT1, SCGB3A1, } \\
\text { HOXC12, PMAIP1, PSIP1, } \\
\text { RPS10-NUDT3, RPS10, } \\
\text { SKOR1, MAP2K5, SIX5, } \\
\text { AGRN, IMMP1L, ELP4, } \\
\text { ITIH4, SEMA3G, POMC, } \\
\text { ADCY3, SSPN, LGR4, TUFM, } \\
\text { MIR4721, SULT1A1, } \\
\text { SULT1A2, APOBR, CLN3, } \\
\text { SPNS1, SH2B1, ATXN2L, } \\
\text { IL27 }\end{array}$ & $\begin{array}{l}28 \text { obesity associated SNPs associate } \\
\text { with methylation levels at } 107 \\
\text { proximal CpG sites, } 38 \text { are located in } \\
\text { the promoter including obesity } \\
\text { relevant genes }\end{array}$ \\
\hline $\begin{array}{l}\text { BMI/ } \\
\text { metabolic } \\
\text { traits }\end{array}$ & $\begin{array}{l}\text { Grundberg } \\
\text { et al. Am J } \\
\text { Hum Genet, } \\
2013 \\
{[94]}\end{array}$ & $648 / n$ & SAT & $\begin{array}{l}\text { Infinium Human } \\
\text { Methylation } 450 \\
\text { BeadChip, } \\
\text { Illumina HT12 } \\
\text { BeadChip, } \\
\text { HumanHap300, } \\
\text { HumanHap610Q, 1M- } \\
\text { Duo, and 1.2MDuo 1M }\end{array}$ & $A D C Y 3$ & $\begin{array}{l}\text { DNA methylation variation was } \\
\text { highly heritable and shared } \\
\text { environmental effects correlated with } \\
\text { metabolic phenotype-associated } \\
\text { CpGs. Analysis of meQTLs revealed } \\
\text { that } 28 \% \text { of CpGs were associated } \\
\text { with nearby SNPs }\end{array}$ \\
\hline MetS & $\begin{array}{l}\text { Guénard et } \\
\text { al. Transl } \\
\text { Res, } 2017 \\
{[87]}\end{array}$ & $31 / \mathrm{n}$ & VAT & $\begin{array}{l}\text { Infinium Human } \\
\text { Methylation } 450 \\
\text { BeadChip, } \\
\text { Affymetrix HG-U133 } \\
\text { plus } 2 \text { arrays, } \\
\text { Illumina HumanOmni-5- } \\
\text { Quad BeadChip }\end{array}$ & COL11A2 & $\begin{array}{l}\text { Identification of } 17800 \text { differing CpG } \\
\text { sites between MetS+ and MetS-, } \\
2182 \text { unique meQTLs associate with } \\
\text { methylation levels at variable CpG } \\
\text { sites. }\end{array}$ \\
\hline $\begin{array}{l}\text { BMI/ } \\
\text { metabolic } \\
\text { traits }\end{array}$ & $\begin{array}{l}\text { Volkov et al. } \\
\text { PLoS ONE, } \\
2016[93]\end{array}$ & $119 / \mathrm{n}$ & SAT & $\begin{array}{l}\text { Infinium Human } \\
\text { Methylation } 450 \\
\text { BeadChip, } \\
\text { whole-transcript } \\
\text { GeneChip@ Human } \\
\text { Gene 1.0 ST Array, } \\
\text { Illumina } \\
\text { HumanOmniExpress }\end{array}$ & $\begin{array}{l}\text { meQTL of known obesity, } \\
\text { lipid, T2D loci: } \\
\text { ADCY3/POMC, } \\
\text { APOA5, CETP, FADS2, } \\
\text { GCKR, SORT1,LEPR } \\
\text { meQTL newly identified: } \\
\text { CHRNA5, } \\
\text { G6PC2, GPX7, RPL27A, }\end{array}$ & $\begin{array}{l}\text { 101,911 SNP-CpG pairs in cis and } \\
5,342 \text { SNP-CpG pairs } \\
\text { in trans were identified in SAT. } \\
\text { Of those meQTL, } 635 \text { SNPs } \\
\text { associate with expression of } 86 \\
\text { genes in SAT and further with } \\
\text { BMI, lipid, glucose and insulin } \\
\text { traits. CIT showed that SNPs in }\end{array}$ \\
\hline
\end{tabular}




\begin{tabular}{|c|c|c|c|c|c|c|}
\hline & & & & BeadChip & THNSL2, ZFP57 & $\begin{array}{l}\text { meQTL impact metabolic traits } \\
\text { through changes in DNA } \\
\text { methylation }\end{array}$ \\
\hline $\begin{array}{l}\text { BMI/age/ } \\
\text { HbA1c }\end{array}$ & $\begin{array}{l}\text { Rönn et al. } \\
\text { Hum Mol } \\
\text { Genet, } 2015 \\
{[80]}\end{array}$ & $190 / y$ & SAT, WB & $\begin{array}{l}\text { Infinium Human } \\
\text { Methylation } 450 \\
\text { BeadChip, } \\
\text { whole-transcript } \\
\text { GeneChip® Human } \\
\text { Gene 1.0 ST Array } \\
\text { (Affymetrix) }\end{array}$ & $\begin{array}{l}\text { BMI: FTO, ITIH5, CCL18, } \\
\text { MTCH2, IRS1, SPP1 }\end{array}$ & $\begin{array}{l}\text { Identification of } 2825 \text { genes where } \\
\text { methylation and expression } \\
\text { correlated with BMI }\end{array}$ \\
\hline BMI & $\begin{array}{l}\text { Keller et al. } \\
\text { Mol Met, } \\
2016[22]\end{array}$ & $77 / y$ & $\begin{array}{l}\text { SAT and } \\
\text { OVAT }\end{array}$ & $\begin{array}{l}\text { MeDIP on Chip, } \\
\text { GeneChip Human } \\
\text { Promoter 1.0R Arrays, } \\
\text { Illumina human } \\
\text { HT-12 expression chips }\end{array}$ & $\begin{array}{l}\text { obesity state specific: ETV6; } \\
\text { tissue specific: } H A N D 2, \\
\text { HOXC6, PPARG, SORBS2, } \\
\text { CD36, CLDN1 }\end{array}$ & $\begin{array}{l}\text { Identification of } 56 \text { adipose depot } \\
\text { specific genes and } 90 \text { obesity state } \\
\text { specific genes which showed } \\
\text { significant promoter methylation } \\
\text { differences and contrary changes of } \\
\text { mRNA expression }\end{array}$ \\
\hline BMI & $\begin{array}{l}\text { Arner et al. } \\
\text { Clin. } \\
\text { Epigenetics, } \\
2015 \text { [84] }\end{array}$ & $29 / n$ & $\begin{array}{l}\text { abdominal } \\
\text { subcutaneous } \\
\text { fat cells }\end{array}$ & $\begin{array}{l}\text { Infinium Human } \\
\text { Methylation } 450 \\
\text { BeadChip, } \\
\text { Illumina Infinium } 27 \mathrm{~K} \\
\text { Human Methylation } \\
\text { Beadchip v1.2, } \\
\text { Gene 1.1 ST Arrays } \\
\text { (Affymetrix) }\end{array}$ & $\begin{array}{l}\text { Adipogenesis: } K L F 15, K L F 5 \text {, } \\
\text { PLIN2, PPARG, PPARGC1A; } \\
\text { Insulin signaling: AKT2, } \\
\text { INSR, IRS1, IRS2 }\end{array}$ & $\begin{array}{l}5529 \text { differentially methylated CpGs } \\
\text { were associated with } 2223 \\
\text { differentially expressed genes } \\
\text { between obese cases and never-obese } \\
\text { controls, candidate genes } \\
\text { overrepresented in pathways for } \\
\text { adipogenesis, insulin signaling and } \\
\text { lipolysis }\end{array}$ \\
\hline BMI & $\begin{array}{l}\text { Wahl et al. } \\
\text { Nature, } 2017 \\
{[24]}\end{array}$ & $5387 / y$ & WB & $\begin{array}{l}\text { Infinium Human } \\
\text { Methylation } 450 \\
\text { BeadChip, } \\
\text { Illumina HumanHT- } \\
12 \text { v3 and v4 } \\
\text { BeadChip array, }\end{array}$ & $\begin{array}{l}\text { ABCG1,LPIN1, HOXA5, } \\
\text { LMNA, CPT1A, SOCS3, } \\
\text { SREBF1, PHGDH }\end{array}$ & $\begin{array}{l}\text { BMI is associated with widespread } \\
\text { changes in DNA methylation ( } 187 \\
\text { genetic). Alterations in DNA } \\
\text { methylation are predominantly the } \\
\text { consequence of adiposity. } \\
\text { Methylation loci are enriched for } \\
\text { functional genomic features in } \\
\text { multiple tissues and show that } \\
\text { sentinel methylation markers identify } \\
\text { gene expression signatures ( } 38 \text { loci). } \\
\text { Loci identify genes involved in lipid } \\
\text { and lipoprotein metabolism, substrate } \\
\text { transport and inflammatory pathways. }\end{array}$ \\
\hline
\end{tabular}


Table 1 summarizes genome wide DNA methylation studies in Caucasian populations for obesity that formed the research field during the last five years. Bold genes were repeatedly identified in several studies. AT=adipose tissue; SAT=subcutaneous AT; OVAT=omental visceral AT; PB=peripheral blood; WB=whole blood; PI=pancreatic islets; MCC-seq=methylation capture sequencing; MeDIP-seq=methylated DNA immunoprecipitation based sequencing; BMI=body mass index; HbA1c= glycosylated hemoglobin; MetS=metabolic syndrome; $\mathrm{y}=\mathrm{yes}$; $\mathrm{n}=\mathrm{no}$; HDL-c=high density lipoprotein-Cholesterol; $\mathrm{CIT}=$ causal interference test; HOMA-IR= Homeostasis Model Assessment based insulin resistance score; FDR=false discovery rate; DMR=differentially methylated regions; meQTL=methylation quantitative trait loci; SNPs=single nucleotide polymorphism;

EWAS=epigenome

wide

association

studies. 
Table 2. Summary of studies that performed candidate gene approaches for DNA methylation in obesity and associated traits

\begin{tabular}{|c|c|c|c|c|c|c|c|}
\hline $\begin{array}{l}\text { Associated } \\
\text { clinical } \\
\text { variable }\end{array}$ & Genes & $\begin{array}{l}\text { Involved pathways } \\
\text { (related to obesity) }\end{array}$ & Study reference & $\begin{array}{l}\text { Tissue } \\
\text { type }\end{array}$ & $\begin{array}{l}\text { Analysis } \\
\text { technique }\end{array}$ & $\begin{array}{l}\text { Population } \\
\text { ancestry } \\
\text { (replicated by) }\end{array}$ & Main findings \\
\hline $\begin{array}{l}\text { overall } \\
\text { obesity }\end{array}$ & POMC & Eating behavior & $\begin{array}{l}\text { Kühnen P. et al. Cell Metab. } \\
2016 \text { [99] } \\
\text { Kuehnen P. et al. PLoS } \\
\text { Genet. 2012 [98] } \\
\text { Volkov P. et al. PLoS One. } \\
2016 \text { [93] } \\
\text { Crujeiras AB. et al. Regul } \\
\text { Pept. } 2013 \text { [100] }\end{array}$ & PBS & $\begin{array}{l}\text { Pyroseq. } \\
\text { bisulfite } \\
\text { seq. } \\
\text { Illumina } \\
450 K \\
\text { MALDI- } \\
\text { TOF } \\
\text { mass } \\
\text { spec. }\end{array}$ & $\begin{array}{l}\text { Caucasians, m } \\
\text { and w } \\
\text { Caucasians } \\
\text { Caucasians, m } \\
\text { and w } \\
\text { Caucasians, m }\end{array}$ & $\begin{array}{l}\text { Meth* of POMC VMR is associated } \\
\text { with BMl; higher meth in obese vs } \\
\text { normal weight adults and children. } \\
\text { Replication in post-mortem MSH- } \\
\text { positive neurons of obese subjects vs } \\
\text { lean. } \\
\text { Rs } 713587 \text { represents meQTL for } \\
P O M C / A D C Y 3 \text { in } \\
\text { Weight regain associates with } \\
\text { increased meth in PBL. }\end{array}$ \\
\hline $\begin{array}{l}\text { overall } \\
\text { obesity }\end{array}$ & $N P Y$ & Eating behavior & $\begin{array}{l}\text { Crujeiras AB. et al. Regul } \\
\text { Pept. } 2013 \text { [100] }\end{array}$ & PBL & $\begin{array}{l}\text { MALDI- } \\
\text { TOF } \\
\text { mass } \\
\text { spec. }\end{array}$ & Caucasians, m & $\begin{array}{l}\text { Low methylation of } N P Y \text { promoter } \\
\text { associates with risk of weight regain }\end{array}$ \\
\hline $\begin{array}{l}\text { overall } \\
\text { obesity }\end{array}$ & SLC6A4 & Reward & $\begin{array}{l}\text { Zhao J. et al. Int J Obes } \\
\text { (Lond). } 2013 \text { [144] } \\
\text { Drabe M. et al. Transl. } \\
\text { Psychiatry. } 2017 \text { [145] }\end{array}$ & $\begin{array}{l}\text { PBL } \\
\text { PBL }\end{array}$ & $\begin{array}{l}\text { Pyroseq. } \\
\text { Pyroseq. }\end{array}$ & $\begin{array}{l}\text { Emory Twin } \\
\text { Studies, } \mathrm{m} \\
\text { Caucasians, } \mathrm{m} \\
\text { and w }\end{array}$ & $\begin{array}{l}\text { Positive correlation with BMI, waist } \\
\text { and } \\
\text { weight; differences in monozygotic } \\
\text { twin pairs discordant for obesity. } \\
\text { Meth of SLC6A4 coding region ( } 5- \\
\text { HTTLPR) correlates negatively with } \\
5 \text {-HTT level in PFC and sensitivity to } \\
\text { reward in obese subjects }\end{array}$ \\
\hline $\begin{array}{l}\text { overall } \\
\text { obesity }\end{array}$ & MCHR1 & Eating behavior & $\begin{array}{l}\text { Stepanow S. et al. PLoS One. } \\
2011 \text { [146] } \\
\text { Perfilyev A. et al. Am J Clin } \\
\text { Nutr. } 2017 \text { [107] }\end{array}$ & $\begin{array}{l}\text { WB } \\
\text { SAT }\end{array}$ & $\begin{array}{l}\text { bisulfite } \\
\text { seq. } \\
\text { Illumina } \\
450 \mathrm{~K}\end{array}$ & $\begin{array}{l}\text { Caucasians, m } \\
\text { Caucasians, } \\
\text { LIPOGAIN cohort }\end{array}$ & $\begin{array}{l}\text { MCHR1 exon1 GT-haplotype specific } \\
\text { meth is decreased with a higher BMI. } \\
\text { DNA meth is associated with weight } \\
\text { gain due to increased energy intake } \\
\text { during HFD }\end{array}$ \\
\hline $\begin{array}{l}\text { overall } \\
\text { obesity }\end{array}$ & FTO & $\begin{array}{l}\mathrm{m} 6 \mathrm{~A} \\
\text { methyltransferase } \\
\text { Glucose/Energy } \\
\text { metabolism }\end{array}$ & $\begin{array}{l}\text { Bell CG. et al. PLoS One } \\
2010 \text { [147] }\end{array}$ & WB & $\begin{array}{l}\text { MeDIP- } \\
\text { chip; } \\
\text { Pyroseq. }\end{array}$ & Caucasians & $\begin{array}{l}\text { Increased DNA meth for obesity } \\
\text { susceptibility haplotype tagged by } \\
\text { rs } 8050136\end{array}$ \\
\hline
\end{tabular}




\begin{tabular}{|c|c|c|c|c|c|c|c|}
\hline $\begin{array}{l}\text { overall } \\
\text { obesity } \\
\text { fat } \\
\text { distribution }\end{array}$ & $A D I P O Q$ & Eating behavior & $\begin{array}{l}\text { Houde AA. et al. BMC Med } \\
\text { Genet. } 2015 \text { [95] } \\
\text { Hjort L. et al. Clin Epigenetics } \\
2017 \text { [96] }\end{array}$ & $\begin{array}{l}\text { WB, } \\
\text { SAT } \\
\text { VAT } \\
\text { SAT } \\
\text { biopsies }\end{array}$ & $\begin{array}{l}\text { Pyroseq. } \\
\text { MassArray } \\
\text { Epityper }\end{array}$ & $\begin{array}{l}\text { Caucasians, } \mathrm{m} \\
\text { and w (French) } \\
\text { Caucasian } \mathrm{m}\end{array}$ & $\begin{array}{l}\text { Meth in SAT is positively associated } \\
\text { to BMI, waist circumference and LDL- } \\
\text { C. } \\
\text { In NBW: DNA meth increases during } \\
\text { fasting; positive association of meth } \\
\text { level with BF\% }\end{array}$ \\
\hline $\begin{array}{l}\text { fat } \\
\text { distribution }\end{array}$ & $L P L$ & Lipid metabolism & $\begin{array}{l}\text { Drogan D. et al. Nutr } \\
\text { Diabetes. } 2015 \text { [148] }\end{array}$ & SAT & $\begin{array}{l}\text { Illumina } \\
450 \mathrm{~K}\end{array}$ & $\begin{array}{l}\text { Caucasians, m } \\
\text { and w; EPIC- } \\
\text { cohort }\end{array}$ & $\begin{array}{l}\text { Meth of one CpG site correlates with } \\
\text { BMI, waist girth, WHR, total \%BF, } \\
\text { SAT and VAT mass and also to } \\
\text { changes of waist, BMl and weight } \\
\text { over } 5 \text { years; further inverse } \\
\text { association to LPL gene expr in SAT }\end{array}$ \\
\hline $\begin{array}{l}\text { fat } \\
\text { distribution }\end{array}$ & IRS1 & Glucose metabolism & $\begin{array}{l}\text { Rohde K. et al. Sci Rep. } 2017 \\
\text { [118] }\end{array}$ & $\begin{array}{l}\text { SAT, } \\
\text { OVAT }\end{array}$ & Pyroseq. & $\begin{array}{l}\text { Caucasians, } \mathrm{m} \\
\text { and } \mathrm{w}\end{array}$ & $\begin{array}{l}\text { Meth differs between SAT and OVAT } \\
\text { and is linked to mRNA expr level in } \\
\text { obese subjects. OVAT meth and expr } \\
\text { associate to waist girth, WHR and } \\
\text { parameters of glucose metabolism in } \\
\text { obese subjects. T-Allele of } \\
\text { rs2943650 near IRS1 is linked to } \\
\text { increased OVAT meth at IRS1 }\end{array}$ \\
\hline $\begin{array}{l}\text { fat } \\
\text { distribution }\end{array}$ & TMEM18 & DNA binding & $\begin{array}{l}\text { Rohde K. et al. J Mol Med. } \\
\text { (Berl) } 2014 \text { [149] }\end{array}$ & $\begin{array}{l}\text { SAT, } \\
\text { OVAT }\end{array}$ & Pyroseq. & $\begin{array}{l}\text { Caucasians, } \mathrm{m} \\
\text { and } \mathrm{w}\end{array}$ & $\begin{array}{l}\text { Lower expr level in SAT than OAVT } \\
\text { while meth shows opposite direction } \\
\text { (strongest in obese subjects); SAT } \\
\text { meth is positively correlated to BMI, } \\
\text { visceral fat area and metabolic traits }\end{array}$ \\
\hline$\% \mathrm{BF}$ & PPARG & Lipid metabolism & $\begin{array}{l}\text { Drogan D. et al. Nutr } \\
\text { Diabetes. } 2015 \text { [148] }\end{array}$ & SAT & $\begin{array}{l}\text { Illumina } \\
450 \mathrm{~K}\end{array}$ & $\begin{array}{l}\text { Caucasians, m } \\
\text { and w; EPIC- } \\
\text { cohort }\end{array}$ & $\begin{array}{l}\text { Meth of one CpG site correlates with } \\
\text { increased \%BF and VAT mass }\end{array}$ \\
\hline $\begin{array}{l}\text { overall } \\
\text { obesity } \\
\text { fat } \\
\text { distribution }\end{array}$ & LEP & Eating behavior & $\begin{array}{l}\text { Houde AA. et al. BMC Med } \\
\text { Genet. } 2015 \text { [95] } \\
\text { Hjort L. et al. Clin Epigenetics } \\
2017 \text { [96] } \\
\text { Obermann-Borst SA. et al. } \\
\text { Pediatr Res. } 2013 \text { [106] }\end{array}$ & $\begin{array}{l}\text { WB, } \\
\text { SAT, } \\
\text { VAT } \\
\text { SAT } \\
\text { biopsies } \\
\text { WB }\end{array}$ & $\begin{array}{l}\text { Pyroseq. } \\
\text { MassArray } \\
\text { Epityper } \\
\text { MassArray } \\
\text { Epityper }\end{array}$ & $\begin{array}{l}\text { Caucasians, m } \\
\text { and w } \\
\text { Caucasian m } \\
\text { Caucasians, } \\
\text { Children }\end{array}$ & $\begin{array}{l}\text { Meth in blood negatively associated } \\
\text { to BMI and positively to LDL-C; in } \\
\text { SAT positively to LDL-C. } \\
\text { Meth increases during fasting in } \\
\text { subjects with NBW; positive } \\
\text { association with BF\% in LBW. } \\
\text { Duration of breast feeding associates } \\
\text { negatively with } L E P \text { meth in offspring; } \\
\text { boys had lower meth than girls. } \\
\text { higher BMl and Leptin level } \\
\text { correlated with lower meth. }\end{array}$ \\
\hline
\end{tabular}




\begin{tabular}{|c|c|c|c|c|c|c|c|}
\hline $\begin{array}{l}\text { fat } \\
\text { distribution } \\
\text { CVD risk }\end{array}$ & IGF2/H19 & $\begin{array}{l}\text { Growth, } \\
\text { Glucose metabolism }\end{array}$ & $\begin{array}{l}\text { Huang R-C. et al. Clin } \\
\text { Epigenetics. } 2012 \text { [150] } \\
\text { Drake AJ. et al. Clinical } \\
\text { Endocrinology. } 2012 \text { [105] }\end{array}$ & PBS & $\begin{array}{l}\text { MassArray } \\
\text { Epityper } \\
\text { MassArray } \\
\text { Epityper } \\
\text { Pyroseq. }\end{array}$ & $\begin{array}{l}\text { 17year old } m \text { and } \\
\text { w; Australian } \\
\text { offspring of } \\
\text { Motherwell cohort } \\
\text { study }\end{array}$ & $\begin{array}{l}\text { Meth of the ICR of IGF2/H19 locus } \\
\text { correlates with higher abdominal skin } \\
\text { fold thickness and subcutaneous } \\
\text { obesity. } \\
\text { Meth correlates with increased } \\
\text { weight, waist, BMI and BP in adult } \\
\text { offspring of mothers who had an } \\
\text { unbalanced diet during pregnancy }\end{array}$ \\
\hline $\begin{array}{l}\text { overall } \\
\text { obesity } \\
\text { CVD risk }\end{array}$ & HSD2 & $\begin{array}{l}\text { Steroid hormone } \\
\text { biology }\end{array}$ & $\begin{array}{l}\text { Drake AJ. et al. Clinical } \\
\text { Endocrinology. } 2012 \text { [105] }\end{array}$ & PBS & Pyroseq. & $\begin{array}{l}\text { offspring of } \\
\text { Motherwell cohort } \\
\text { study }\end{array}$ & $\begin{array}{l}\text { Meth is associated with adult } \\
\text { obesity and increased systolic BP in } \\
\text { offspring of mothers with an } \\
\text { unbalanced diet during pregnancy }\end{array}$ \\
\hline $\begin{array}{l}\text { overall } \\
\text { obesity } \\
\text { CVD risk }\end{array}$ & GR & $\begin{array}{l}\text { Steroid hormone } \\
\text { biology }\end{array}$ & $\begin{array}{l}\text { Drake AJ. et al. Clinical } \\
\text { Endocrinology. } 2012 \text { [105] }\end{array}$ & PBS & Pyroseq. & $\begin{array}{l}\text { offspring of } \\
\text { Motherwell cohort } \\
\text { study }\end{array}$ & $\begin{array}{l}\text { Meth correlates with increased waist, } \\
\text { BMl and weight } \\
\text { while meth in GR exon1 is inversely } \\
\text { associated to BP }\end{array}$ \\
\hline $\begin{array}{l}\text { overall } \\
\text { obesity } \\
\text { CVD risk }\end{array}$ & SREBF1 & $\begin{array}{l}\text { Cholesterol and lipid } \\
\text { metabolism }\end{array}$ & $\begin{array}{l}\text { Mendelson MM. et al. PLoS } \\
\text { Med 2017 [151] } \\
\text { Wahl S. et al. Nature } 2017 \\
\text { [24] }\end{array}$ & blood & $\begin{array}{l}\text { Illumina } \\
450 \mathrm{~K} \\
\text { Illumina } \\
450 \mathrm{~K}\end{array}$ & $\begin{array}{l}\text { FHS offspring } \\
\text { cohort; LBCs of } \\
1921 \text { and } 1936 \\
\text { from the Scottish } \\
\text { Mtal Surveys } \\
\text { KORA (EUR) and } \\
\text { LOLIPOP (IA) }\end{array}$ & $\begin{array}{l}\text { Differential meth and expr of } \\
\text { SREBF1 in relation to BMl; further } \\
\text { relations to other adiposity traits and } \\
\text { CAD } \\
\text { DNA meth in blood is correlated to } \\
\text { BMI }\end{array}$ \\
\hline $\begin{array}{l}\text { dyslipidemia } \\
\text { CVD risk }\end{array}$ & $A B C A 1$ & $\begin{array}{l}\text { Cholesterol and lipid } \\
\text { metabolism }\end{array}$ & $\begin{array}{l}\text { Guay S-P. et al. Clin } \\
\text { Epigenetics. } 2014 \text { [152] }\end{array}$ & $\begin{array}{l}\text { leucocyte } \\
\text { s }\end{array}$ & Pyroseq. & $\mathrm{m}$ & $\begin{array}{l}\text { Meth associates with aging and CAD; } \\
\text { older men represent higher meth } \\
\text { which is correlated with higher total } \\
\text { C, LDL-C and TG level }\end{array}$ \\
\hline $\begin{array}{l}\text { fat } \\
\text { distribution } \\
\text { dyslipidemia }\end{array}$ & TNFA & $\begin{array}{l}\text { Proinflammatory } \\
\text { cytokine; lipid } \\
\text { metabolism }\end{array}$ & $\begin{array}{l}\text { Hermsdorff HH. et al. } \\
\text { Cytokine. } 2013 \text { [104] }\end{array}$ & WB & $\begin{array}{l}\text { MassArray } \\
\text { Epityper }\end{array}$ & Caucasian w & $\begin{array}{l}\text { Higher meth at TNFA in women with } \\
\text { lower truncal fat; meth further } \\
\text { correlates to circulating TNFA level. } \\
\text { Meth explained by central fat, HDL- } \\
\text { cholesterol, insulin, plasma TNFa, } \\
\text { and daily n-6 PUFA intake }\end{array}$ \\
\hline dyslipidemia & CD36 & $\begin{array}{l}\text { Eating behavior, lipid } \\
\text { metabolism }\end{array}$ & $\begin{array}{l}\text { Love-Gregory L. et al. J Lipid } \\
\text { Res. } 2016 \text { [153] }\end{array}$ & WB, SAT & $\begin{array}{l}\text { Illumina } \\
450 \mathrm{~K}\end{array}$ & $\begin{array}{l}\text { Caucasians, m } \\
\text { and w; GOLDN } \\
\text { cohort; MuTHER } \\
\text { cohort }\end{array}$ & $\begin{array}{l}\text { SNPs in } C D 36 \text { associating with LDL- } \\
\mathrm{C} \text { level and } C D 36 \text { expr, the latter } \\
\text { correlates further to its meth in SAT; } \\
\text { hypo-meth associate to lower } C D 36 \\
\text { gene expr in SAT }\end{array}$ \\
\hline dyslipidemia & PHGDH & Amino acid synthesis & $\begin{array}{l}\text { Truong V. et al. Sci Rep. } 2017 \\
\text { [113] }\end{array}$ & WB & $\begin{array}{l}\text { Illumina } \\
450 K ; \\
\text { bisulfite } \\
\text { RT-qPCR }\end{array}$ & $\begin{array}{l}\text { F5L familiy study, } \\
\text { MuTHER cohort }\end{array}$ & $\begin{array}{l}\text { High meth in blood at one CpG site } \\
\text { correlates negatively with blood-TG } \\
\text { level; variation of TG level explain } \\
\text { variance in meth by } 6-13 \% \\
\text { depending on study cohort }\end{array}$ \\
\hline
\end{tabular}




\begin{tabular}{|c|c|c|c|c|c|c|c|}
\hline $\begin{array}{l}\text { overall } \\
\text { obesity } \\
\text { dyslipidemia }\end{array}$ & TOMM20 & mitophagy & $\begin{array}{l}\text { de Toro-Martín, J. et al. } \\
\text { Diabetol Metab Syndr. } 2016 \\
\text { [111] }\end{array}$ & VAT & $\begin{array}{l}\text { Illumina } \\
450 \mathrm{~K}\end{array}$ & $\begin{array}{l}\mathrm{m} \text { and } \mathrm{w} \\
\text { (Canadian) }\end{array}$ & $\begin{array}{l}4 \text { meQTLs were identified in VAT of } \\
\text { severe obese subjects while carriers } \\
\text { are related to either high plasma TG } \\
\text { level or low total C level }\end{array}$ \\
\hline $\begin{array}{l}\text { overall } \\
\text { obesity } \\
\text { dyslipidemia } \\
\text { T2D }\end{array}$ & $A B C G 1$ & $\begin{array}{l}\text { Cholesterol and lipid } \\
\text { metabolism }\end{array}$ & $\begin{array}{l}\text { Pfeiffer L. et al. Circ } \\
\text { Cardiovasc Genet. } 2015 \text { [110] } \\
\text { Truong V. et al. Sci Rep. } 2017 \\
\text { [113] } \\
\text { Dayeh T. et al. Epigenetics } \\
2016 \text { [154] } \\
\text { Wahl S. et al. Nature } 2017 \\
\text { [24] }\end{array}$ & $\begin{array}{l}\text { WB } \\
\text { WB } \\
\text { blood, AT } \\
\text { blood }\end{array}$ & $\begin{array}{l}\text { Illumina } \\
450 \mathrm{~K} \\
\text { Illumina } \\
450 \mathrm{~K} \\
\text { Illumina } \\
450 \mathrm{~K} ; \\
\text { Pyroseq. } \\
\\
\text { Illumina } \\
450 \mathrm{~K}\end{array}$ & $\begin{array}{l}\text { Caucasians, m } \\
\text { and w } \\
\text { KORA F4 study; } \\
\text { KORA F3 and } \\
\text { InCHIANTI; } \\
\text { MuTHER cohort } \\
\text { F5L familiy study, } \\
\text { MuTHER cohort } \\
\text { Caucasioans, } \\
\text { Bosnia prospective } \\
\text { study } \\
\text { KORA (EUR) and } \\
\text { LOLIPOP (IA) }\end{array}$ & $\begin{array}{l}\text { ABCG1 top candidate for negative } \\
\text { association of meth with HDL-C and } \\
\text { TG level and its gene expr in blood. } \\
\text { Meth in blood correlates positively } \\
\text { with blood TG level. } \\
\text { Meth in blood associate with future } \\
\text { risk of T2D and is positively } \\
\text { correlated with BMI, HbA1c, Fl and } \\
\text { TG; DNA methylation in blood and } \\
\text { AT differs from monozygotic twins } \\
\text { discordant for } \\
\text { DNA meth in blood associates with } \\
\text { BMl }\end{array}$ \\
\hline $\begin{array}{l}\text { overall } \\
\text { obesity } \\
\text { dyslipidemia } \\
\text { T2D }\end{array}$ & PHOSPHO1 & $\begin{array}{l}\text { Phospholipid } \\
\text { metabolism }\end{array}$ & $\begin{array}{l}\text { Dayeh T. et al. Epigenetics } \\
2016 \text { [154] } \\
\text { Wahl S. et al. Nature } 2017 \\
\text { [24] }\end{array}$ & blood & $\begin{array}{l}\text { Illumina } \\
450 K ; \\
\text { Pyroseq. } \\
\text { Illumina } \\
450 K\end{array}$ & $\begin{array}{l}\text { Caucasians, } \\
\text { Bosnia prospective } \\
\text { study } \\
\text { KORA (EUR) and } \\
\text { LOLIPOP (IA) }\end{array}$ & $\begin{array}{l}\text { Meth in blood is associated with } \\
\text { future risk of T2D and increased HDL } \\
\text { level in blood; differential meth in } \\
\text { blood and AT from monozygotic twins } \\
\text { discordant for tor T2D. } \\
\text { DNA meth in blood is correlated to } \\
\text { BMl }\end{array}$ \\
\hline $\begin{array}{l}\% B F \\
\text { MetS }\end{array}$ & $\begin{array}{l}\text { Clock- } \\
\text { genes } \\
\text { (BMAL1, } \\
\text { PER2, } \\
\text { CLOCK) }\end{array}$ & Circadian rythm & $\begin{array}{l}\text { Milagro F.I. et al. Chronobiol } \\
\text { Int. } 2012 \text { [101] }\end{array}$ & WB & $\begin{array}{l}\text { MassArray } \\
\text { Epityper }\end{array}$ & $\begin{array}{l}\text { Caucasians, } \mathrm{m} \\
\text { and } \mathrm{w}\end{array}$ & $\begin{array}{l}\text { Meth of CLOCK and BMAL1 differs in } \\
\text { normal weight and overweight+obese } \\
\text { subjects; meth of all } 3 \text { genes } \\
\text { correlated positively to one or all } \\
\text { factors: \%BF, BMl and MetS score; } \\
\% \text { meth of CLOCK correlated with } \\
\text { intake of fatty acids }\end{array}$ \\
\hline $\begin{array}{l}\text { overall } \\
\text { obesity } \\
\text { MetS }\end{array}$ & PER3 & Circadian rythm & $\begin{array}{l}\text { Samblas M. et al. Pediatr } \\
\text { Obes. 2018 [102] } \\
\text { Ramos-Lopez O. et al. } \\
\text { Chronobiol Int. } 2018 \text { [103] }\end{array}$ & $\begin{array}{l}\text { WB } \\
\text { WB }\end{array}$ & $\begin{array}{l}\text { Illumina } \\
\text { 450K; } \\
\text { MassArray } \\
\text { Epityper } \\
\text { Illumina } \\
450 \mathrm{~K}\end{array}$ & $\begin{array}{l}\text { children; GENOI } \\
\text { study } \\
\text { Caucasians, m } \\
\text { and w; MA project }\end{array}$ & $\begin{array}{l}\text { Differences between normal weight } \\
\text { and obese children; correlation to } \\
\text { BMI } \\
\text { Meth in blood correlates to BMI also } \\
\text { in adults and further to IR and BP }\end{array}$ \\
\hline $\begin{array}{l}\text { fat } \\
\text { distribution } \\
\text { MetS }\end{array}$ & HIF3A & Hypoxia & $\begin{array}{l}\text { Pfeiffer S. et al. Sci. Rep. } \\
2016 \text { [77] }\end{array}$ & $\begin{array}{l}\text { blood, } \\
\text { SAT, } \\
\text { OVAT } \\
\text { blood, }\end{array}$ & Pyroseq. & $\begin{array}{l}\text { Caucasians, } \mathrm{m} \\
\text { and } \mathrm{w}\end{array}$ & $\begin{array}{l}\text { Tissue specific meth; associations } \\
\text { with mRNA expr, fat distribution, } \\
\text { adiponectin level; obese subjects } \\
\text { displayed highest HIF3A meth. } \\
\text { Meth in blood correlates with BMI }\end{array}$ \\
\hline
\end{tabular}




\begin{tabular}{|c|c|c|c|c|c|c|c|}
\hline & & & $\begin{array}{l}\text { Main AM. et al. Clin } \\
\text { Epigenetics } 2016 \text { [76] } \\
\text { Wang S. et al. PLoS One } \\
2015 \text { [79] }\end{array}$ & . & $\begin{array}{l}\text { MassArray } \\
\text { Epityper }\end{array}$ & $\begin{array}{l}\text { Caucasians, m } \\
\text { and w } \\
\text { EUGENE2 } \\
\text { Consortium } \\
\text { children; CPOOA } \\
\text { study (CHN) }\end{array}$ & $\begin{array}{l}\text { and meth in SAT; meth in SAT is } \\
\text { dependent on family relatedness; no } \\
\text { correlation to gene expr in SAT, while } \\
\text { gene expr is related to HbA1c level. } \\
\text { Higher meth of } 2 \mathrm{CpGs} \text { in obese vs. } \\
\text { normal weight children; positive } \\
\text { correlation to parameters of MetS }\end{array}$ \\
\hline $\begin{array}{l}\text { \%BF } \\
\text { diabetes }\end{array}$ & TXNIP & $\begin{array}{l}\text { Oxidative stress, } \\
\text { hyperglycemia }\end{array}$ & $\begin{array}{l}\text { Houshmand-Oeregaard A. et } \\
\text { al. } \\
\text { PLoS One } 2017 \text { [155] }\end{array}$ & $\begin{array}{l}\text { SAT } \\
\text { biopsies }\end{array}$ & Pyroseq. & $\begin{array}{l}\text { Caucasians, } \mathrm{m} \\
\text { and } \mathrm{w}\end{array}$ & $\begin{array}{l}\text { Higher meth while lower gene exp in } \\
\text { SAT in offspring of mothers with GD; } \\
\text { meth in SAT correlates negatively } \\
\text { with \%BF and 120min plasma insulin } \\
\text { level }\end{array}$ \\
\hline T2D & PEG3 & DNA binding & $\begin{array}{l}\text { van Otterdijk, SD. et al. PLoS } \\
\text { One } 2017 \text { [156] }\end{array}$ & PBL & Pyroseq. & $\begin{array}{l}\text { Caucasians, } \mathrm{m} \\
\text { and } \mathrm{w}\end{array}$ & $\begin{array}{l}\text { PEG3 meth higher in MetS patients } \\
\text { compared to subjects with only T2D }\end{array}$ \\
\hline $\begin{array}{l}\text { fat } \\
\text { distribution } \\
\text { diabetes } \\
\text { inflammation }\end{array}$ & $L Y 86$ & $\begin{array}{l}\text { Cytokine, immune } \\
\text { system }\end{array}$ & $\begin{array}{l}\text { Su S. et al. Twin Res Hum } \\
\text { Genet. } 2014 \text { [108] }\end{array}$ & PBS & $\begin{array}{l}\text { Illumina } \\
27 \mathrm{~K} \\
\text { Beadchip } \\
\text { Pyroseq. }\end{array}$ & $\begin{array}{l}m \text { and } w(A A \text { and } \\
E A)\end{array}$ & $\begin{array}{l}\text { Associations with increased } \mathrm{BMI} \text { and } \\
\% \mathrm{BF} \text {, parameters of IR and } \\
\text { increased CRP level }\end{array}$ \\
\hline $\begin{array}{l}\text { overall } \\
\text { obesity } \\
\text { inflammation }\end{array}$ & ADRB3 & $\begin{array}{l}\text { Lipolysis, } \\
\text { thermogenesis }\end{array}$ & $\begin{array}{l}\text { Lima RPA. et al. Clin } \\
\text { Epigenetics. } 2017 \text { [109] }\end{array}$ & WB & Pyroseq. & Caucasians, w & $\begin{array}{l}\text { Hazel nut oil in diet reduces DNA } \\
\text { meth of } A D R B 3 \text { of obese and } \\
\text { overweight women; improved level of } \\
\text { HDL-C and total antioxidant capacity }\end{array}$ \\
\hline
\end{tabular}

Table 2 summarizes candidate gene approaches for DNA methylation in obesity and related traits in blood and AT including top genes identified in recent epigenome wide studies. Only human observational studies in adult Caucasians have been taken into account. T2D=type 2 diabetes; \%BF=\% body fat ; CVD=cardio vascular diseases; $\mathrm{CAD}=$ coronary artery diseases; MetS=metabolic syndrome ; AT=adipose tissue; WAT=white AT; SAT=subcutaneous AT; OVAT=omental visceral AT; $\mathrm{PBL}=$ peripheral blood leukocytes; PBS=peripheral blood samples; WB=whole blood; Pyro(seq)=Pyro(sequencing); $\mathrm{m}=\mathrm{men}$; w=women; meth=CpG DNA methylation (meth*=ALU-element methylation); expr=gene expression; NBW=normal birth weight; LBW=low birth weight; ICR=imprinting control region; $\mathrm{BP}=$ blood pressure; IR=insulin resistance; FI=fasting insulin; HbA1c=glycosylated hemoglobin; VMR=variable methylated region; HFD=high fat diet; $\mathrm{CRP}=\mathrm{C}-$ reactive protein; HDL-c=high density lipoprotein-cholesterol; LDL-c=high density lipoprotein-cholesterol; total $\mathrm{c}=$ total cholesterol; TG=triglycerides; meQTL=methylation quantitative trait loci; $\mathrm{GD}=$ gestational diabetes, WHR=waist to hip ratio; $\mathrm{MSH}=$ melanocortin stimulating hormone; $\mathrm{SNP}=$ single nucleotide polymorphism 


\section{References:}

[1] Ng M, Fleming T, Robinson M, Thomson B, Graetz N, Margono C, et al. Global, regional, and national prevalence of overweight and obesity in children and adults during 1980-2013: a systematic analysis for the Global Burden of Disease Study 2013. Lancet (London, England). 2014;384:766-81.

[2] Fontaine KR, Redden DT, Wang C, Westfall AO, Allison DB. Years of life lost due to obesity. Jama. 2003;289:187-93.

[3] Bluher M. Adipose tissue inflammation: a cause or consequence of obesity-related insulin resistance? Clinical science (London, England : 1979). 2016;130:1603-14.

[4] Long E, Beales IL. The role of obesity in oesophageal cancer development. Therapeutic advances in gastroenterology. 2014;7:247-68.

[5] Rosso N, Chavez-Tapia NC, Tiribelli C, Bellentani S. Translational approaches: from fatty liver to non-alcoholic steatohepatitis. World journal of gastroenterology. 2014;20:9038-49.

[6] Katzmarzyk PT, Perusse L, Rao DC, Bouchard C. Familial risk of overweight and obesity in the Canadian population using the WHO/NIH criteria. Obes Res. 2000;8:194-7.

[7] Koeppen-Schomerus G, Wardle J, Plomin R. A genetic analysis of weight and overweight in 4-yearold twin pairs. International journal of obesity and related metabolic disorders : journal of the International Association for the Study of Obesity. 2001;25:838-44.

[8] Pietilainen KH, Kaprio J, Rissanen A, Winter T, Rimpela A, Viken RJ, et al. Distribution and heritability of BMI in Finnish adolescents aged 16y and 17y: a study of 4884 twins and 2509 singletons. International journal of obesity and related metabolic disorders : journal of the International Association for the Study of Obesity. 1999;23:107-15.

[9] Allison DB, Kaprio J, Korkeila M, Koskenvuo M, Neale MC, Hayakawa K. The heritability of body mass index among an international sample of monozygotic twins reared apart. International journal of obesity and related metabolic disorders : journal of the International Association for the Study of Obesity. 1996;20:501-6.

[10] Feinleib M, Garrison RJ, Fabsitz R, Christian JC, Hrubec Z, Borhani NO, et al. The NHLBI twin study of cardiovascular disease risk factors: methodology and summary of results. American journal of epidemiology. 1977;106:284-5.

[11] Stunkard AJ, Foch TT, Hrubec Z. A twin study of human obesity. Jama. 1986;256:51-4.

[12] Stunkard AJ, Harris JR, Pedersen NL, McClearn GE. The body-mass index of twins who have been reared apart. N Engl J Med. 1990;322:1483-7.

[13] Stunkard AJ, Sorensen TI, Hanis C, Teasdale TW, Chakraborty R, Schull WJ, et al. An adoption study of human obesity. N Engl J Med. 1986;314:193-8.

[14] Fesinmeyer MD, North KE, Ritchie MD, Lim U, Franceschini N, Wilkens LR, et al. Genetic risk factors for BMI and obesity in an ethnically diverse population: results from the population architecture using genomics and epidemiology (PAGE) study. Obesity (Silver Spring, Md). 2013;21:835-46.

[15] Locke AE, Kahali B, Berndt SI, Justice AE, Pers TH, Day FR, et al. Genetic studies of body mass index yield new insights for obesity biology. Nature. 2015;518:197-206.

[16] Shungin D, Winkler TW, Croteau-Chonka DC, Ferreira T, Locke AE, Mägi R, et al. New genetic loci link adipose and insulin biology to body fat distribution. Nature. 2015;518:187-96.

[17] Ng MCY, Graff M, Lu Y, Justice AE, Mudgal P, Liu CT, et al. Discovery and fine-mapping of adiposity loci using high density imputation of genome-wide association studies in individuals of African ancestry: African Ancestry Anthropometry Genetics Consortium. PLoS Genet. 2017;13:e1006719.

[18] Wheeler E, Leong A, Liu CT, Hivert MF, Strawbridge RJ, Podmore C, et al. Impact of common genetic determinants of Hemoglobin A1c on type 2 diabetes risk and diagnosis in ancestrally diverse populations: A transethnic genome-wide meta-analysis. PLoS Med. 2017;14:e1002383. 
[19] Yengo L, Sidorenko J, Kemper KE, Zheng Z, Wood AR, Weedon MN, et al. Meta-analysis of genome-wide association studies for height and body mass index in 700,000 individuals of European ancestry. bioRxiv 274654 This article is a preprint and has not been peer-reviewed 2018.

[20] Yang J, Bakshi A, Zhu Z, Hemani G, Vinkhuyzen AA, Lee SH, et al. Genetic variance estimation with imputed variants finds negligible missing heritability for human height and body mass index. Nat Genet. 2015;47:1114-20.

[21] Barres R, Kirchner H, Rasmussen M, Yan J, Kantor FR, Krook A, et al. Weight loss after gastric bypass surgery in human obesity remodels promoter methylation. Cell Rep. 2013;3:1020-7.

[22] Keller M, Hopp L, Liu X, Wohland T, Rohde K, Cancello R, et al. Genome-wide DNA promoter methylation and transcriptome analysis in human adipose tissue unravels novel candidate genes for obesity. Mol Metab. 2017;6:86-100.

[23] Nilsson E, Jansson PA, Perfilyev A, Volkov P, Pedersen M, Svensson MK, et al. Altered DNA Methylation and Differential Expression of Genes Influencing Metabolism and Inflammation in Adipose Tissue From Subjects With Type 2 Diabetes. Diabetes. 2014;63:2962-76.

[24] Wahl S, Drong A, Lehne B, Loh M, Scott WR, Kunze S, et al. Epigenome-wide association study of body mass index, and the adverse outcomes of adiposity. Nature. 2017;541:81-6.

[25] Kaur Y, de Souza RJ, Gibson WT, Meyre D. A systematic review of genetic syndromes with obesity. Obesity reviews : an official journal of the International Association for the Study of Obesity. 2017;18:603-34.

[26] Bonnefond A, Raimondo A, Stutzmann F, Ghoussaini M, Ramachandrappa S, Bersten DC, et al. Loss-of-function mutations in SIM1 contribute to obesity and Prader-Willi-like features. The Journal of clinical investigation. 2013;123:3037-41.

[27] Pigeyre M, Yazdi FT, Kaur Y, Meyre D. Recent progress in genetics, epigenetics and metagenomics unveils the pathophysiology of human obesity. Clinical science (London, England : 1979). 2016;130:943-86.

[28] Saeed S, Arslan M, Froguel P. Genetics of Obesity in Consanguineous Populations: Toward Precision Medicine and the Discovery of Novel Obesity Genes. Obesity (Silver Spring, Md). 2018;26:474-84.

[29] Ingelsson E, McCarthy MI. Human Genetics of Obesity and Type 2 Diabetes Mellitus: Past, Present, and Future. Circulation Genomic and precision medicine. 2018;11:e002090.

[30] Choquet H, Meyre D. Molecular basis of obesity: current status and future prospects. Current genomics. 2011;12:154-68.

[31] Huvenne H, Dubern B, Clement K, Poitou C. Rare Genetic Forms of Obesity: Clinical Approach and Current Treatments in 2016. Obesity facts. 2016;9:158-73.

[32] Zhang Y, Proenca R, Maffei M, Barone M, Leopold L, Friedman JM. Positional cloning of the mouse obese gene and its human homologue. Nature. 1994;372:425-32.

[33] Morton GJ, Meek TH, Schwartz MW. Neurobiology of food intake in health and disease. Nature reviews Neuroscience. 2014;15:367-78.

[34] Farooqi IS, Jebb SA, Langmack G, Lawrence E, Cheetham CH, Prentice AM, et al. Effects of recombinant leptin therapy in a child with congenital leptin deficiency. N Engl J Med. 1999;341:87984.

[35] Farooqi IS, Matarese G, Lord GM, Keogh JM, Lawrence E, Agwu C, et al. Beneficial effects of leptin on obesity, $\mathrm{T}$ cell hyporesponsiveness, and neuroendocrine/metabolic dysfunction of human congenital leptin deficiency. The Journal of clinical investigation. 2002;110:1093-103.

[36] Licinio J, Caglayan S, Ozata M, Yildiz BO, de Miranda PB, O'Kirwan F, et al. Phenotypic effects of leptin replacement on morbid obesity, diabetes mellitus, hypogonadism, and behavior in leptindeficient adults. Proc Natl Acad Sci U S A. 2004;101:4531-6.

[37] Ozata M, Ozdemir IC, Licinio J. Human leptin deficiency caused by a missense mutation: multiple endocrine defects, decreased sympathetic tone, and immune system dysfunction indicate new targets for leptin action, greater central than peripheral resistance to the effects of leptin, and spontaneous correction of leptin-mediated defects. The Journal of clinical endocrinology and metabolism. 1999;84:3686-95. 
[38] Krude H, Biebermann H, Luck W, Horn R, Brabant G, Gruters A. Severe early-onset obesity, adrenal insufficiency and red hair pigmentation caused by POMC mutations in humans. Nat Genet. 1998;19:155-7.

[39] Farooqi IS, Keogh JM, Yeo GS, Lank EJ, Cheetham T, O'Rahilly S. Clinical spectrum of obesity and mutations in the melanocortin 4 receptor gene. N Engl J Med. 2003;348:1085-95.

[40] Farooqi IS, Yeo GS, Keogh JM, Aminian S, Jebb SA, Butler G, et al. Dominant and recessive inheritance of morbid obesity associated with melanocortin 4 receptor deficiency. The Journal of clinical investigation. 2000;106:271-9.

[41] Vaisse C, Clement K, Durand E, Hercberg S, Guy-Grand B, Froguel P. Melanocortin-4 receptor mutations are a frequent and heterogeneous cause of morbid obesity. The Journal of clinical investigation. 2000;106:253-62.

[42] Pritchard LE, Turnbull AV, White A. Pro-opiomelanocortin processing in the hypothalamus: impact on melanocortin signalling and obesity. The Journal of endocrinology. 2002;172:411-21.

[43] Jackson RS, Creemers JW, Ohagi S, Raffin-Sanson ML, Sanders L, Montague CT, et al. Obesity and impaired prohormone processing associated with mutations in the human prohormone convertase 1 gene. Nat Genet. 1997;16:303-6.

[44] O'Rahilly S, Gray H, Humphreys PJ, Krook A, Polonsky KS, White A, et al. Brief report: impaired processing of prohormones associated with abnormalities of glucose homeostasis and adrenal function. N Engl J Med. 1995;333:1386-90.

[45] Goshu E, Jin H, Fasnacht R, Sepenski M, Michaud JL, Fan CM. Sim2 mutants have developmental defects not overlapping with those of Sim1 mutants. Molecular and cellular biology. 2002;22:4147-57. [46] Holder JL, Jr., Butte NF, Zinn AR. Profound obesity associated with a balanced translocation that disrupts the SIM1 gene. Hum Mol Genet. 2000;9:101-8.

[47] Ramachandrappa S, Raimondo A, Cali AM, Keogh JM, Henning E, Saeed S, et al. Rare variants in single-minded 1 (SIM1) are associated with severe obesity. The Journal of clinical investigation. 2013;123:3042-50.

[48] Frayling TM, Timpson NJ, Weedon MN, Zeggini E, Freathy RM, Lindgren CM, et al. A common variant in the FTO gene is associated with body mass index and predisposes to childhood and adult obesity. Science. 2007;316:889-94.

[49] Akiyama M, Okada Y, Kanai M, Takahashi A, Momozawa Y, Ikeda M, et al. Genome-wide association study identifies 112 new loci for body mass index in the Japanese population. Nat Genet. 2017;49:1458-67.

[50] Ho EV, Klenotich SJ, McMurray MS, Dulawa SC. Activity-Based Anorexia Alters the Expression of BDNF Transcripts in the Mesocorticolimbic Reward Circuit. PloS one. 2016;11:e0166756.

[51] Horstmann A, Kovacs $P$, Kabisch S, Boettcher $Y$, Schloegl H, Tonjes A, et al. Common genetic variation near MC4R has a sex-specific impact on human brain structure and eating behavior. PloS one. 2013;8:e74362.

[52] Boender AJ, van Rozen AJ, Adan RA. Nutritional state affects the expression of the obesityassociated genes Etv5, Faim2, Fto, and Negr1. Obesity (Silver Spring, Md). 2012;20:2420-5.

[53] Locke AE, Kahali B, Berndt SI, Justice AE, Pers TH, Day FR, et al. Genetic studies of body mass index yield new insights for obesity biology. Nature. 2015;518:197-206.

[54] Kilpelainen TO, Zillikens MC, Stancakova A, Finucane FM, Ried JS, Langenberg C, et al. Genetic variation near IRS1 associates with reduced adiposity and an impaired metabolic profile. Nature genetics. 2011;43:753-60.

[55] Shungin D, Winkler TW, Croteau-Chonka DC, Ferreira T, Locke AE, Magi R, et al. New genetic loci link adipose and insulin biology to body fat distribution. Nature. 2015;518:187-96.

[56] Su LN, Wang YB, Wnag CG, Wei HP. Network analysis identifies common genes associated with obesity in six obesity-related diseases. Journal of Zhejiang University Science B. 2017;18:727-32.

[57] Benzinou M, Creemers JW, Choquet H, Lobbens S, Dina C, Durand E, et al. Common nonsynonymous variants in PCSK1 confer risk of obesity. Nat Genet. 2008;40:943-5. 
[58] Choquet H, Kasberger J, Hamidovic A, Jorgenson E. Contribution of common PCSK1 genetic variants to obesity in 8,359 subjects from multi-ethnic American population. PLoS One. 2013;8:e57857.

[59] Rouskas K, Kouvatsi A, Paletas K, Papazoglou D, Tsapas A, Lobbens S, et al. Common variants in FTO, MC4R, TMEM18, PRL, AIF1, and PCSK1 show evidence of association with adult obesity in the Greek population. Obesity (Silver Spring, Md). 2012;20:389-95.

[60] Loos RJ, Lindgren CM, Li S, Wheeler E, Zhao JH, Prokopenko I, et al. Common variants near MC4R are associated with fat mass, weight and risk of obesity. Nat Genet. 2008;40:768-75.

[61] Claussnitzer M, Dankel SN, Kim K-H, Quon G, Meuleman W, Haugen C, et al. FTO Obesity Variant Circuitry and Adipocyte Browning in Humans. The New England journal of medicine. 2015;373:895907.

[62] Andreasen CH, Stender-Petersen KL, Mogensen MS, Torekov SS, Wegner L, Andersen G, et al. Low physical activity accentuates the effect of the FTO rs9939609 polymorphism on body fat accumulation. Diabetes. 2008;57:95-101.

[63] Ahmad T, Lee IM, Pare G, Chasman DI, Rose L, Ridker PM, et al. Lifestyle interaction with fat mass and obesity-associated (FTO) genotype and risk of obesity in apparently healthy U.S. women. Diabetes Care. 2011;34:675-80.

[64] Li S, Zhao JH, Luan J, Ekelund U, Luben RN, Khaw KT, et al. Physical activity attenuates the genetic predisposition to obesity in 20,000 men and women from EPIC-Norfolk prospective population study. PLoS Med. 2010;7.

[65] Qi Q, Chu AY, Kang JH, Jensen MK, Curhan GC, Pasquale LR, et al. Sugar-sweetened beverages and genetic risk of obesity. N Engl J Med. 2012;367:1387-96.

[66] Zhang X, Qi Q, Zhang C, Smith SR, Hu FB, Sacks FM, et al. FTO genotype and 2-year change in body composition and fat distribution in response to weight-loss diets: the POUNDS LOST Trial. Diabetes. 2012;61:3005-11.

[67] de Luis DA, Aller R, Izaola O, de la Fuente B, Conde R, Sagrado MG, et al. Evaluation of weight loss and adipocytokines levels after two hypocaloric diets with different macronutrient distribution in obese subjects with rs9939609 gene variant. Diabetes/metabolism research and reviews. 2012;28:663-8.

[68] Huang T, Hu FB. Gene-environment interactions and obesity: recent developments and future directions. BMC medical genomics. 2015;8 Suppl 1:S2.

[69] Aschard H, Chen J, Cornelis MC, Chibnik LB, Karlson EW, Kraft P. Inclusion of gene-gene and gene-environment interactions unlikely to dramatically improve risk prediction for complex diseases. American journal of human genetics. 2012;90:962-72.

[70] Kaprio J. Twins and the mystery of missing heritability: the contribution of gene-environment interactions. Journal of internal medicine. 2012;272:440-8.

[71] Lewin B. The Mystique of Epigenetics. Cell. 1998;93:4.

[72] Wu C-t, Morris JR. Genes, Genetics, and Epigenetics: A Correspondence. Epigenetics. 2001;293:3.

[73] Deaton AM, Bird A. CpG islands and the regulation of transcription. Genes Dev. 2011;25:1010-22.

[74] Weber M, Schubeler D. Genomic patterns of DNA methylation: targets and function of an epigenetic mark. Curr Opin Cell Biol. 2007;19:273-80.

[75] Dick KJ, Nelson CP, Tsaprouni L, Sandling JK, Aïssi D, Wahl S, et al. DNA methylation and bodymass index: a genome-wide analysis. The Lancet. 2014;383:1990-8.

[76] Main AM, Gillberg L, Jacobsen AL, Nilsson E, Gjesing AP, Hansen T, et al. DNA methylation and gene expression of HIF3A: cross-tissue validation and associations with $\mathrm{BMI}$ and insulin resistance. Clinical epigenetics. 2016;8:89.

[77] Pfeiffer S, Kruger J, Maierhofer A, Bottcher Y, Kloting N, El Hajj N, et al. Hypoxia-inducible factor $3 \mathrm{~A}$ gene expression and methylation in adipose tissue is related to adipose tissue dysfunction. Sci Rep. 2016;6:27969.

[78] Richmond RC, Sharp GC, Ward ME, Fraser A, Lyttleton O, McArdle WL, et al. DNA Methylation and BMI: Investigating Identified Methylation Sites at HIF3A in a Causal Framework. Diabetes. 2016;65:1231-44. 
[79] Wang S, Song J, Yang Y, Zhang Y, Wang H, Ma J. HIF3A DNA Methylation Is Associated with Childhood Obesity and ALT. PloS one. 2015;10:e0145944.

[80] Ronn T, Volkov P, Gillberg L, Kokosar M, Perfilyev A, Jacobsen AL, et al. Impact of age, BMI and HbA1c levels on the genome-wide DNA methylation and mRNA expression patterns in human adipose tissue and identification of epigenetic biomarkers in blood. Hum Mol Genet. 2015;24:3792813.

[81] Keller M, Kralisch S, Rohde K, Schleinitz D, Dietrich A, Schon MR, et al. Global DNA methylation levels in human adipose tissue are related to fat distribution and glucose homeostasis. Diabetologia. 2014;57:2374-83.

[82] Grundberg E, Meduri E, Sandling JK, Hedman AK, Keildson S, Buil A, et al. Global analysis of DNA methylation variation in adipose tissue from twins reveals links to disease-associated variants in distal regulatory elements. Am J Hum Genet. 2013;93:876-90.

[83] Dahlman I, Sinha I, Gao H, Brodin D, Thorell A, Ryden M, et al. The fat cell epigenetic signature in post-obese women is characterized by global hypomethylation and differential DNA methylation of adipogenesis genes. Int J Obes (Lond). 2015;39:910-9.

[84] Arner P, Sinha I, Thorell A, Ryden M, Dahlman-Wright K, Dahlman I. The epigenetic signature of subcutaneous fat cells is linked to altered expression of genes implicated in lipid metabolism in obese women. Clinical epigenetics. 2015;7:93.

[85] Voisin S, Almen MS, Zheleznyakova GY, Lundberg L, Zarei S, Castillo S, et al. Many obesityassociated SNPs strongly associate with DNA methylation changes at proximal promoters and enhancers. Genome Med. 2015;7:103.

[86] Guenard F, Tchernof A, Deshaies Y, Perusse L, Biron S, Lescelleur O, et al. Differential methylation in visceral adipose tissue of obese men discordant for metabolic disturbances. Physiological genomics. 2014;46:216-22.

[87] Guenard F, Tchernof A, Deshaies Y, Biron S, Lescelleur O, Biertho L, et al. Genetic regulation of differentially methylated genes in visceral adipose tissue of severely obese men discordant for the metabolic syndrome. Translational research : the journal of laboratory and clinical medicine. 2017;184:1-11.e2.

[88] Allum F, Shao X, Guenard F, Simon MM, Busche S, Caron M, et al. Characterization of functional methylomes by next-generation capture sequencing identifies novel disease-associated variants. Nat Commun. 2015;6:7211.

[89] Despres JP, Lemieux I. Abdominal obesity and metabolic syndrome. Nature. 2006;444:881-7.

[90] Rönn T, Volkov P, Davegårdh C, Dayeh T, Hall E, Olsson AH, et al. A Six Months Exercise Intervention Influences the Genome-wide DNA Methylation Pattern in Human Adipose Tissue. PLoS Genetics. 2013;9:e1003572.

[91] Johansson LE, Danielsson AP, Parikh H, Klintenberg M, Norstrom F, Groop L, et al. Differential gene expression in adipose tissue from obese human subjects during weight loss and weight maintenance. Am J Clin Nutr. 2012;96:196-207.

[92] Aron-Wisnewsky J, Julia Z, Poitou C, Bouillot JL, Basdevant A, Chapman MJ, et al. Effect of bariatric surgery-induced weight loss on SR-BI-, ABCG1-, and ABCA1-mediated cellular cholesterol efflux in obese women. J Clin Endocrinol Metab. 2011;96:1151-9.

[93] Volkov P, Olsson AH, Gillberg L, Jorgensen SW, Brons C, Eriksson KF, et al. A Genome-Wide mQTL Analysis in Human Adipose Tissue Identifies Genetic Variants Associated with DNA Methylation, Gene Expression and Metabolic Traits. PLoS One. 2016;11:e0157776.

[94] Grundberg E, Meduri E, Sandling JK, Hedman AK, Keildson S, Buil A, et al. Global analysis of DNA methylation variation in adipose tissue from twins reveals links to disease-associated variants in distal regulatory elements. American journal of human genetics. 2013;93:876-90.

[95] Houde AA, Legare C, Biron S, Lescelleur O, Biertho L, Marceau S, et al. Leptin and adiponectin DNA methylation levels in adipose tissues and blood cells are associated with BMI, waist girth and LDL-cholesterol levels in severely obese men and women. BMC Med Genet. 2015;16:29. 
[96] Hjort L, Jorgensen SW, Gillberg L, Hall E, Brons C, Frystyk J, et al. $36 \mathrm{~h}$ fasting of young men influences adipose tissue DNA methylation of LEP and ADIPOQ in a birth weight-dependent manner. Clin Epigenetics. 2017;9:40.

[97] Millington GW. The role of proopiomelanocortin (POMC) neurones in feeding behaviour. Nutr Metab (Lond). 2007;4:18.

[98] Kuehnen P, Mischke M, Wiegand S, Sers C, Horsthemke B, Lau S, et al. An Alu elementassociated hypermethylation variant of the POMC gene is associated with childhood obesity. PLoS Genet. 2012;8:e1002543.

[99] Kuhnen P, Handke D, Waterland RA, Hennig BJ, Silver M, Fulford AJ, et al. Interindividual Variation in DNA Methylation at a Putative POMC Metastable Epiallele Is Associated with Obesity. Cell Metab. 2016;24:502-9.

[100] Crujeiras AB, Campion J, Diaz-Lagares A, Milagro Fl, Goyenechea E, Abete I, et al. Association of weight regain with specific methylation levels in the NPY and POMC promoters in leukocytes of obese men: a translational study. Regul Pept. 2013;186:1-6.

[101] Milagro FI, Gomez-Abellan P, Campion J, Martinez JA, Ordovas JM, Garaulet M. CLOCK, PER2 and BMAL1 DNA methylation: association with obesity and metabolic syndrome characteristics and monounsaturated fat intake. Chronobiol Int. 2012;29:1180-94.

[102] Samblas M, Milagro FI, Mansego ML, Marti A, Martinez JA, members G. PTPRS and PER3 methylation levels are associated with childhood obesity: results from a genome-wide methylation analysis. Pediatr Obes. 2018;13:149-58.

[103] Ramos-Lopez O, Samblas M, Milagro FI, Riezu-Boj JI, Crujeiras AB, Martinez JA, et al. Circadian gene methylation profiles are associated with obesity, metabolic disturbances and carbohydrate intake. Chronobiol Int. 2018:1-13.

[104] Hermsdorff HH, Mansego ML, Campion J, Milagro FI, Zulet MA, Martinez JA. TNF-alpha promoter methylation in peripheral white blood cells: relationship with circulating TNFalpha, truncal fat and n-6 PUFA intake in young women. Cytokine. 2013;64:265-71.

[105] Drake AJ, McPherson RC, Godfrey KM, Cooper C, Lillycrop KA, Hanson MA, et al. An unbalanced maternal diet in pregnancy associates with offspring epigenetic changes in genes controlling glucocorticoid action and foetal growth. Clin Endocrinol (Oxf). 2012;77:808-15.

[106] Obermann-Borst SA, Eilers PH, Tobi EW, de Jong FH, Slagboom PE, Heijmans BT, et al. Duration of breastfeeding and gender are associated with methylation of the LEPTIN gene in very young children. Pediatr Res. 2013;74:344-9.

[107] Perfilyev A, Dahlman I, Gillberg L, Rosqvist F, Iggman D, Volkov P, et al. Impact of polyunsaturated and saturated fat overfeeding on the DNA-methylation pattern in human adipose tissue: a randomized controlled trial. The American journal of clinical nutrition. 2017;105:991-1000.

[108] Su S, Zhu H, Xu X, Wang X, Dong Y, Kapuku G, et al. DNA methylation of the LY86 gene is associated with obesity, insulin resistance, and inflammation. Twin Res Hum Genet. 2014;17:183-91.

[109] Lima RPA, do Nascimento RAF, Luna RCP, Persuhn DC, da Silva AS, da Conceicao Rodrigues Goncalves $\mathrm{M}$, et al. Effect of a diet containing folate and hazelnut oil capsule on the methylation level of the ADRB3 gene, lipid profile and oxidative stress in overweight or obese women. Clin Epigenetics. 2017;9:110.

[110] Pfeiffer L, Wahl S, Pilling LC, Reischl E, Sandling JK, Kunze S, et al. DNA methylation of lipidrelated genes affects blood lipid levels. Circ Cardiovasc Genet. 2015;8:334-42.

[111] de Toro-Martin J, Guenard F, Tchernof A, Deshaies Y, Perusse L, Hould FS, et al. Methylation quantitative trait loci within the TOMM20 gene are associated with metabolic syndrome-related lipid alterations in severely obese subjects. Diabetol Metab Syndr. 2016;8:55.

[112] Guay S-P, Légaré C, Houde AA, Mathieu P, Bossé Y, Bouchard L. Acetylsalicylic acid, aging and coronary artery disease are associated with ABCA1 DNA methylation in men. Clinical Epigenetics. 2014;6:7.

[113] Truong V, Huang S, Dennis J, Lemire M, Zwingerman N, Aissi D, et al. Blood triglyceride levels are associated with DNA methylation at the serine metabolism gene PHGDH. Scientific reports. 2017;7:11207. 
[114] Braun KVE, Dhana K, de Vries PS, Voortman T, van Meurs JBJ, Uitterlinden AG, et al. Epigenome-wide association study (EWAS) on lipids: the Rotterdam Study. Clin Epigenetics. 2017;9:15.

[115] Dekkers KF, van Iterson M, Slieker RC, Moed MH, Bonder MJ, van Galen M, et al. Blood lipids influence DNA methylation in circulating cells. Genome Biol. 2016;17:138.

[116] Keller M, Klos M, Rohde K, Kruger J, Kurze T, Dietrich A, et al. DNA methylation of SSPN is linked to adipose tissue distribution and glucose metabolism. Faseb j. 2018:fj201800528R.

[117] Rohde K, Keller M, Klös M, Schleinitz D, Dietrich A, Schön MR, et al. Adipose tissue depot specific promoter methylation of TMEM18. Journal of Molecular Medicine. 2014;92:881-8.

[118] Rohde K, Klos M, Hopp L, Liu X, Keller M, Stumvoll M, et al. IRS1 DNA promoter methylation and expression in human adipose tissue are related to fat distribution and metabolic traits. Scientific reports. 2017;7:12369.

[119] Barrès R, Yan J, Egan B, Treebak JT, Rasmussen M, Fritz T, et al. Acute Exercise Remodels Promoter Methylation in Human Skeletal Muscle. Cell Metabolism. 2012;15:405-11.

[120] Lund J, Rustan AC, Lovsletten NG, Mudry JM, Langleite TM, Feng YZ, et al. Exercise in vivo marks human myotubes in vitro: Training-induced increase in lipid metabolism. PLoS One. 2017;12:e0175441.

[121] Bajpeyi S, Covington JD, Taylor EM, Stewart LK, Galgani JE, Henagan TM. Skeletal Muscle PGC1alpha -1 Nucleosome Position and -260 nt DNA Methylation Determine Exercise Response and Prevent Ectopic Lipid Accumulation in Men. Endocrinology. 2017;158:2190-9.

[122] Fabre O, Ingerslev LR, Garde C, Donkin I, Simar D, Barres R. Exercise training alters the genomic response to acute exercise in human adipose tissue. Epigenomics. 2018.

[123] Ingerslev LR, Donkin I, Fabre O, Versteyhe S, Mechta M, Pattamaprapanont P, et al. Endurance training remodels sperm-borne small RNA expression and methylation at neurological gene hotspots.

Clin Epigenetics. 2018;10:12.

[124] Bluher S, Kapplinger J, Herget S, Reichardt S, Bottcher Y, Grimm A, et al. Cardiometabolic risk markers, adipocyte fatty acid binding protein (aFABP) and the impact of high-intensity interval training (HIIT) in obese adolescents. Metabolism. 2017;68:77-87.

[125] Kirchner H, Nylen C, Laber S, Barres R, Yan J, Krook A, et al. Altered promoter methylation of PDK4, IL1 B, IL6, and TNF after Roux-en Y gastric bypass. Surg Obes Relat Dis. 2014;10:671-8.

[126] Day SE, Garcia LA, Coletta RL, Campbell LE, Benjamin TR, De Filippis EA, et al. Alterations of sorbin and SH3 domain containing 3 (SORBS3) in human skeletal muscle following Roux-en-Y gastric bypass surgery. Clin Epigenetics. 2017;9:96.

[127] Benton MC, Johnstone A, Eccles D, Harmon B, Hayes MT, Lea RA, et al. An analysis of DNA methylation in human adipose tissue reveals differential modification of obesity genes before and after gastric bypass and weight loss. Genome biology. 2015;16:8.

[128] Macartney-Coxson D, Benton MC, Blick R, Stubbs RS, Hagan RD, Langston MA. Genome-wide DNA methylation analysis reveals loci that distinguish different types of adipose tissue in obese individuals. Clin Epigenetics. 2017;9:48.

[129] Morcillo S, Martin-Nunez GM, Garcia-Serrano S, Gutierrez-Repiso C, Rodriguez-Pacheco F, Valdes $S$, et al. Changes in SCD gene DNA methylation after bariatric surgery in morbidly obese patients are associated with free fatty acids. Scientific reports. 2017;7:46292.

[130] Bostrom AE, Mwinyi J, Voisin S, Wu W, Schultes B, Zhang K, et al. Longitudinal genome-wide methylation study of Roux-en-Y gastric bypass patients reveals novel $\mathrm{CpG}$ sites associated with essential hypertension. BMC medical genomics. 2016;9:20.

[131] Berglind D, Muller P, Willmer M, Sinha I, Tynelius P, Naslund E, et al. Differential methylation in inflammation and type 2 diabetes genes in siblings born before and after maternal bariatric surgery. Obesity (Silver Spring, Md). 2016;24:250-61.

[132] Donkin I, Versteyhe S, Ingerslev LR, Qian K, Mechta M, Nordkap L, et al. Obesity and Bariatric Surgery Drive Epigenetic Variation of Spermatozoa in Humans. Cell Metabolism. 2015;23:369-78. 
[133] Clement K, Biebermann H, Farooqi IS, Van der Ploeg L, Wolters B, Poitou C, et al. MC4R agonism promotes durable weight loss in patients with leptin receptor deficiency. Nat Med. 2018;24:551-5.

[134] Kuhnen P, Clement K, Wiegand S, Blankenstein O, Gottesdiener K, Martini LL, et al. Proopiomelanocortin Deficiency Treated with a Melanocortin-4 Receptor Agonist. N Engl J Med. 2016;375:240-6.

[135] Santoro N, Perrone L, Cirillo G, Raimondo P, Amato A, Coppola F, et al. Weight loss in obese children carrying the proopiomelanocortin R236G variant. Journal of endocrinological investigation. 2006;29:226-30.

[136] Reinehr T, Hebebrand J, Friedel S, Toschke AM, Brumm H, Biebermann $H$, et al. Lifestyle intervention in obese children with variations in the melanocortin 4 receptor gene. Obesity (Silver Spring, Md). 2009;17:382-9.

[137] Feero WG, Guttmacher AE. Genomics, personalized medicine, and pediatrics. Academic pediatrics. 2014;14:14-22.

[138] Alyass A, Turcotte M, Meyre D. From big data analysis to personalized medicine for all: challenges and opportunities. BMC medical genomics. 2015;8:33.

[139] Hood L, Flores M. A personal view on systems medicine and the emergence of proactive P4 medicine: predictive, preventive, personalized and participatory. New biotechnology. 2012;29:61324.

[140] Ng MC, Bowden DW. Is genetic testing of value in predicting and treating obesity? North Carolina medical journal. 2013;74:530-3.

[141] Loos RJ. Genetic determinants of common obesity and their value in prediction. Best practice \& research Clinical endocrinology \& metabolism. 2012;26:211-26.

[142] Collins FS, Varmus H. A new initiative on precision medicine. N Engl J Med. 2015;372:793-5.

[143] Aslibekyan S, Demerath EW, Mendelson M, Zhi D, Guan W, Liang L, et al. Epigenome-wide study identifies novel methylation loci associated with body mass index and waist circumference. Obesity (Silver Spring, Md). 2015;23:1493-501.

[144] Zhao J, Goldberg J, Vaccarino V. Promoter methylation of serotonin transporter gene is associated with obesity measures: a monozygotic twin study. Int J Obes (Lond). 2013;37:140-5.

[145] Drabe M, Rullmann M, Luthardt J, Boettcher $Y$, Regenthal R, Ploetz $T$, et al. Serotonin transporter gene promoter methylation status correlates with in vivo prefrontal 5-HTT availability and reward function in human obesity. Transl Psychiatry. 2017;7:e1167.

[146] Stepanow S, Reichwald K, Huse K, Gausmann U, Nebel A, Rosenstiel P, et al. Allele-specific, agedependent and BMI-associated DNA methylation of human MCHR1. PLoS One. 2011;6:e17711.

[147] Bell CG, Finer S, Lindgren CM, Wilson GA, Rakyan VK, Teschendorff AE, et al. Integrated genetic and epigenetic analysis identifies haplotype-specific methylation in the FTO type 2 diabetes and obesity susceptibility locus. PloS one. 2010;5:e14040.

[148] Drogan D, Boeing H, Janke J, Schmitt B, Zhou Y, Walter J, et al. Regional distribution of body fat in relation to DNA methylation within the LPL, ADIPOQ and PPARgamma promoters in subcutaneous adipose tissue. Nutr Diabetes. 2015;5:e168.

[149] Rohde K, Keller M, Klos M, Schleinitz D, Dietrich A, Schon MR, et al. Adipose tissue depot specific promoter methylation of TMEM18. J Mol Med (Berl). 2014;92:881-8.

[150] Huang RC, Galati JC, Burrows S, Beilin LJ, Li X, Pennell CE, et al. DNA methylation of the IGF2/H19 imprinting control region and adiposity distribution in young adults. Clinical epigenetics. 2012;4:21.

[151] Mendelson MM, Marioni RE, Joehanes R, Liu C, Hedman AK, Aslibekyan S, et al. Association of Body Mass Index with DNA Methylation and Gene Expression in Blood Cells and Relations to Cardiometabolic Disease: A Mendelian Randomization Approach. PLoS Med. 2017;14:e1002215.

[152] Guay SP, Legare C, Houde AA, Mathieu P, Bosse Y, Bouchard L. Acetylsalicylic acid, aging and coronary artery disease are associated with ABCA1 DNA methylation in men. Clinical epigenetics. 2014;6:14. 
[153] Love-Gregory L, Kraja AT, Allum F, Aslibekyan S, Hedman AK, Duan Y, et al. Higher chylomicron remnants and LDL particle numbers associate with CD36 SNPs and DNA methylation sites that reduce CD36. J Lipid Res. 2016;57:2176-84.

[154] Dayeh T, Tuomi T, Almgren P, Perfilyev A, Jansson PA, de Mello VD, et al. DNA methylation of loci within ABCG1 and PHOSPHO1 in blood DNA is associated with future type 2 diabetes risk. Epigenetics. 2016;11:482-8.

[155] Houshmand-Oeregaard A, Hjort L, Kelstrup L, Hansen NS, Broholm C, Gillberg L, et al. DNA methylation and gene expression of TXNIP in adult offspring of women with diabetes in pregnancy. PLoS One. 2017;12:e0187038.

[156] van Otterdijk SD, Binder AM, Szarc Vel Szic K, Schwald J, Michels KB. DNA methylation of candidate genes in peripheral blood from patients with type 2 diabetes or the metabolic syndrome. PLoS One. 2017;12:e0180955. 